\title{
Stakeholder Perception of the Determinants of Audit Committee Effectiveness in a Developing Economy: Evidence from the Libyan Banking Sector
}

\author{
Abdulhakim M. Masli \\ Nottingham Trent University, 50 Shakespeare St, \\ Nottingham NG1 4FQ, United Kingdom, and Faculty of Economics, Misurata University, \\ Misurata City, PO Box 2478, Libya \\ a.masli@eps.misuratau.edu.ly \\ Musa Mangena \\ University of Nottingham Business School, Wollaton Rd, Lenton, Nottingham NG8 \\ 1BB, United Kingdom \\ Musa.Mangena@nottingham.ac.uk
}

\begin{abstract}
Ali M. Gerged*
Corresponding Author

Leicester Castle Business School, De Montfort University,

The Gateway, Leicester, LE1 9BH, United Kingdom, and Faculty of Economics, Misurata University, Misurata City, PO Box 2478, Libya

ali.gerged@dmu.ac.uk

\section{Donald Harradine}

Nottingham Trent University

50 Shakespeare St, Nottingham NG1 4FQ

United Kingdom

donald.harradine@ntu.ac.uk

Masli, H., Mangena, M., Gerged, A, M., \& Harradine, D. (2021). Stakeholder Perception of the Determinants of Audit Committee Effectiveness in a Developing Economy: Evidence from the Libyan Banking Sector, Journal of Accounting in Emerging Economies, Forthcoming. DOI: 10.1108/JAEE-09-2019-0182
\end{abstract}




\title{
Stakeholder Perception of the Determinants of Audit Committee Effectiveness in a Developing Economy: Evidence from the Libyan Banking Sector
}

\begin{abstract}
Purpose - This study distinctively explores the firm-level and national-level determinants of Audit Committee Effectiveness (ACE) in the Libyan banking sector (LBS).

Design/methodology/approach - A mixed-methods approach has been employed to enhance the quality of the collected data and reduce the risk of bias. Five groups of actors in the Libyan banking sector were surveyed, including board members, AC members, executive managers, internal auditors and external auditors, further to interviewing a representative sample of these groups. In total, 218 survey responses were gathered, and 20 semi-structured interviews were conducted.
\end{abstract}

Findings - Our results show that $A C$ authority, financial expertise, and diligence are positively and significantly attributed to ACE, although AC independence and resources are not significantly related to ACE. We find that the legal and regulatory environment, government intervention, and the accounting and auditing environment are perceived as important and associated with ACE regarding national-level factors. These findings are strongly supported by semi-structured interviews and suggest that both firm-level and national-level factors are essential in understanding ACE in Libya's banking sector.

Research implications - Our evidence reiterates the vital need for more concentrated work to integrate governance, legislative and regulatory reforms to ensure the effectiveness of ACs as a key corporate governance (CG) mechanism in developing economies.

Originality/value - Our study extends the literature relating measures of $A C$ inputs and outputs by examining the perception of stakeholders to understand both the firm-level and national-level factors that affect ACE in a single institutional setting. Additionally, our work adds to the limited number of recent studies examining the role of ACs in the banking sector in developing economies.

Keywords: Audit committee effectiveness, Banking sector, Corporate governance, Firm-level determinants, Libya, National-level Determinants.

\section{Introduction}

In the light of episodes of corporate failures and collapses around the world that attributed to weak control mechanisms (Suchan, 2004; Stewart, 2006), the need for greater transparency to protect shareholders and stakeholders alike have been highlighted (Glaum et al., 2004; Fearnley and Beattie, 2004). In most of the developed world, regulatory and 
policy responses have been to enact laws (e.g., the Sarbanes Oxley Act (SOX), 2002) or to develop best practice guidance (e.g., UK Corporate Governance Code, 2018) to improve corporate governance quality (Albitar et al., 2020). An important outcome of these responses was establishing the audit committee $(A C)$, whose responsibility is to take oversight of the quality of financial reporting and corporate accountability. These developments culminated in extensive research examining the relationship between $\mathrm{AC}$ attributes (inputs) (e.g., independence, expertise, diligence) and different measures of financial reporting quality (the outputs), mostly in the developed countries (see Ghafran and O'Sullivan, 2013 for the most recent and extensive review). While prior research provides important insights into the effects of ACs, calls for further research have been made to provide an understanding of (1) the processes by which they contribute to corporate governance (see Turley and Zaman, 2014; Beasley et al., 2009), (2) how stakeholders view the work of the AC (Spira and Bender, 2004; Jun Lin et al., 2006) and (3) ACs in institutional contexts other than the most developed countries (Mangena and Chamisa, 2008; Ghafran and O'Sullivan, 2013).

In this study, we respond to the last two calls and attempt to contribute to the existing AC literature. In particular, we investigate the views of stakeholders about the role and effectiveness of ACs and the factors facilitating and inhibiting their operations in the Libyan banking sector. We believe this is interesting and important for two reasons. First, we do not only contribute to the AC inputs-outputs relationship studies, but we also provide insights on the roles of ACs in developing countries, where the regulatory framework for corporate governance (CG) is weak (see Leuz, 2003; Boubakri et al., 2005). In relation to this, Okpara (2011) find in Nigeria that there are constraints that hinder the implementation and promotion of CG, including weak or non-existent law enforcement mechanisms. Mangena and Tauringana (2007) point to the rife corruption and the meddling of politics in 
corporate affairs as major impediments to governance effectiveness in Africa. Thus, examining $A C$ in these settings would provide important insights that cannot be drawn in developed countries where institutional structures for corporate governance arrangements are strong. This is particularly so because the degree to which the $A C$ can be effective in its role is affected by factors within the environment in which the firm operates (Mangena and Chamisa, 2008; Baxter, 2010; Ghafran and O'Sullivan, 2013). However, we know very little about ACs in developing countries, particularly in Africa, a continent perceived as risky due to weak investor protection laws (Gerged et al., 2021a; Nuskiya et al., 2021; Klapper and Love, 2004; Mangena and Tauringana, 2007; Waweru et al., 2019).

Second, we examine ACs in the banking sector in contrast to most studies that focus on nonfinancial companies. Studies with a focus on CG in banking sectors in general, and ACs, in particular, are generally limited. Yet, the banking sector holds a peculiar positionnot only do they have an important role in the economy in general but they are also considered as playing a key role in monitoring other companies (see Macey and O'Hara, 2003). However, there has been an emerging stream of studies on CG and bank outcomes since the 2007-2009 financial crisis (e.g., Aebi et al., 2012; Dermine, 013; Jizi et al., 2014), but the paucity of studies examining ACs in banking institutions remains. The exceptions are Barakat and Hussainey (2013), who examine risk reporting and Sun and Liu (2014), analysing the effects of ACs on risk-taking. Our paper seeks to contribute to these emerging studies by investigating stakeholders' perceptions of AC effectiveness in the Libyan banking sector. This is important because the AC is one important CG mechanism upon which stakeholders can be assured that the behaviour of managers will be constrained (Gendron and Bedard, 2006). Therefore, how ACs are perceived by stakeholders, particularly in the banking sector, has a bearing on trust and confidence in the bank. 
We believe examining the AC in the Libyan banking sector is important. First, Libya recently opened up the economy to privatisation and foreign investment (Gerged and Almontaser, 2021; Masoud, 2014). To support these initiatives, the Libyan Stock Market (LSM) established in 2007 the Libyan Corporate Governance Code (LCGC ) for listed companies. The LCGC covers key areas, including the responsibilities of the board of directors, the establishment of sub-committees such as the audit committee, remuneration committee, nomination committee and watchdog committee, and the requirements of disclosure and transparency. Thus, unlike many other African countries, CG implementation in Libya is at a very infant stage, particularly in the banking sector (Masli, 2018). Larbsh (2010) and Abdou (2015) also notes that the CG regulatory framework in Libya remains particularly inadequate compared to other African countries. Thus, it is important for research to understand the role and effectiveness of the AC in Libya to aid policymakers in their attempt to strengthen the quality of corporate governance and provide reassurance to investors, both locally and internationally, that their investment will be safeguarded.

Second, the banking sector is one of the most important sectors of the Libyan economy and plays a major role in financing projects and businesses (Shernanna, 2012). It operates under LCGC as well as the 2005 Central Bank of Libya (CBL) corporate governance code (CBL-CGC) (Masli, 2018). The CBL-CGC requires banks to establish various board committees, including the audit committee (Zagoub, 2011). However, there is very little understanding of their effectiveness and the factors influencing the work. Thus, our study attempts to address this gap by investigating the views of the stakeholders, in particular, the board of directors (including AC members), executive managers, and both internal and external auditors, on the effectiveness of the ACs in Libya's banking sector. 
Using a mixed-methods approach, our study contributes to the literature in several ways. First, we extend the literature relating measures of $A C$ inputs and outputs (e.g., Raghunandan and Rama, 2007; Sharma et al., 2009; see also Ghafran and O'Sullivan, 2013 for a review). Our paper differs from this literature in that we investigate the perception of stakeholders to understand both the firm-level and national-level factors that affect ACE. Second, we extend and complement AC works in developed countries to developing countries with a different operating setting for ACs (see Leuz, 2003; Boubakri et al., 2005; Mangena and Tauringana, 2007). Our findings show that even in a setting such as Libya, factors such as authority, financial expertise, and diligence of the AC are perceived as important, which is in line with prior work. Additionally, our analyses of the effects of institutional factors on ACE also extends prior work. Third, in contrast to most studies that examine ACs in nonfinancial companies, we focus on ACs in the banking sector. In this case, our work adds to the limited number of recent studies examining the role of CG, and ACs in particular, in the banking sector (see Barakat and Hussainey, 2013; Sun and Liu, 2014). Whereas these studies focus on risk reporting and risk-taking effects of ACs, we survey stakeholders on the factors influencing ACE. Fourth, we contribute to the few studies examining AC effectiveness in the Libyan context. For example, Masli et al. (2019) examine how the shift to an Islamic banking system in Libya affects ACs' operations but does not examine factors affecting the AC's effectiveness. Finally, our results have implications for regulators and policymakers as they provide insights into the factors that enhance and/or inhibit ACs effectiveness in Libya.

The rest of the paper is structured as follows. In the next section, we provide a brief discussion of corporate governance in the Libyan banking sector. Section 3 discusses the related literature and discusses the theoretical underpinning and hypotheses in Section 4. 
The research design is discussed in Section 5. We present the empirical results in Section 6, and in Section 7, we discuss our main findings. Finally, section 8 concludes the paper.

\section{Audit committees in the Libyan banking sector}

The Libyan banking sector comprises the central bank of Libya (CBL), 17 commercial banks and four specialised banks (CBL, 2016). The CBL was established in 1956 to act as Libya's supreme monetary authority that aims to maintain financial stability and ensure continuous growth of the Libyan economic system in line with the country's overall economic policy (CBL, 2008). It has the authority to oversee or supervise all of Libya's banks, ensuring the integrity of their financial position and protect the depositors and clients' rights (El-Firjani et al., 2014). Over the last 20 years, the Libyan government opened the country to foreign investment (Gerged and Almontaser, 2021; Masoud, 2014). Consequently, from 2002 to 2010 , the CBL applied measures to bring the banking sector into line with the Libyan government's new policies in order to facilitate economic development. These measures included reforming commercial banks, issuing CG code in 2005, transferring public banks' ownership to the private sector, and allowing foreign investors to enter the sector (CBL, 2010b). As a consequence of these measures, the commercial banks are now diversely owned by the private sector, the Libyan state, or jointowned by a combination of the state, local and foreign investors (Libyan-foreign) (Gerged and Almontaser, 2021). Given this, some foreign banks were allowed to own up to $50 \%$ of the Libyan commercial banks' shares and participate in their management (Kumati, 2008). For example, in 2008, the First Gulf Bank (FGB) - a UAE based bank - owned about $50 \%$ of the capital of the Libyan bank of Gumhouria, which was the fifteenth foreign bank operating in Libya by the end of 2010 (Elsakit, 2017). Together, the commercial banks manage a total of 494 branches across Libya's regions and hold assets of 98.4 billion Libyan dinars ( $£ 46.8$ billion) in 2016 (CBL, 2016). The four specialised banks were 
established to finance specific commercial activities. In particular, the Agricultural Bank provides agricultural loans, the Alrefi Bank grants loans to job seekers, the Development Bank funds investment in industry, and the Eddekhar Bank offers mortgages (CBL, 2016). In supervising the banking sector, the CBL applies the recommendations of the Basel Committee to measure the soundness of the banks. In addition to the supervision or monitoring by the CBL, banks are also recommended to adopt the LCGC as well as the CBL-CGC. Whereas the LCGC applies to all listed companies, the CBL-CGC is specifically for all Libyan banks. The CBL-CGC was developed in 2005 and the LCGC in 2007, and at that time, both recommended the establishment of the audit committee. Larbsh (2010) show that these recommendations became more prevalent in listed firms. For the banking sector, the CBL-CGC were revised in 2010, and the establishment of ACs became mandatory (CBL, 2010a). The audit committee has several roles, such as observing the fairness and transparency of financial statements, reviewing the internal audit plan, overseeing external auditors' work, and confirming the sufficiency and effectiveness of internal control systems (CBL, 2010a). Additionally, ACs are responsible for advising on the appointment or replacement of the external auditor and the internal audit unit director and supporting the board with reports to assist it in assessing banks' financial performance (Shalba, 2016). In brief, the audit committee is thus a crucial CG structure, aiding the board to fulfil its duties successfully and protect shareholders' interests. The CBL-CGC requires the AC to consist of a minimum of four directors, at least two of whom should be independent. Some of the audit committee members should have experience in risk management, financial disclosure, accounting, and auditing. At its chairman's invitation, an audit committee ought to meet at least once every three months or whenever needed. It should also hold periodic meetings, at least annually, with the external auditor and the chief of the internal audit department. 


\section{Related studies}

Our paper is related to two strands of CG literature. One strand, which is the most dominant, examines the relationship between $A C$ attributes and financial reporting quality measures, mostly in developed countries such as the US, the UK, Canada, and Europe (see Ghafran and O'Sullivan, 2013 for the most recent review). In summary, this literature provides evidence on the roles of ACs and their responsibilities (e.g. Keune and Johnstone, 2012; Turley and Zaman, 2014); the causes and consequences of AC effectiveness (e.g. Klein, 2002; McDaniel et al., 2002; Mangena and Pike, 2005; Ghafran and O'Sullivan, 2017; Poretti et al., 2018). Within this literature, studies focusing on developing countries are growing (e.g., Mangena and Chamisa, 2008; Gerged and Agwili, 2020; Gerged, 2021). Taken all together, studies in both developed and developing countries suggest that audit committees are important, and the AC attributes influence their effectiveness. However, the effects of these attributes appear to be institutional contextspecific-that is, attributes that are found to be important differ depending on the institutional setting of the study (see Ghafran and O'Sullivan, 2013; Chanda et al., 2017). However, there is little research focused on understanding the institutional factors influencing the AC's effectiveness.

The second strand of studies attempts to understand AC effectiveness by garnering views of stakeholders instead of examining the $A C$ inputs-outputs relationship. These studies use interviews and questionnaire surveys to understand processes and factors affecting AC effectiveness (e.g., Spira and Bender, 2004; Cohen et al., 2002, 2004; Turley and Zaman, 2014; Beasley et al., 2009). Spira and Bender (2004) interviewed AC chairs, finance directors, and auditors to understand whether the AC's role was ceremonial or whether the AC provided comfort in the financial reporting process. Both studies concluded that the role of $A C$ members was ceremonial; that is, the $A C$ is not effective. Cohen et al. 
(2002) interviewed auditors to understand their perception of the effects of ACs on the audit process and found that auditors considered ACs as weak and ineffective. However, in their later study, following the introduction of SOX, the auditors' perceived the ACs as more diligent, expert and powerful, suggesting that strong regulation improves effectiveness. Turley and Zaman (2014) examined the interactions of the AC with other stakeholders, including board members, financial reporting people and internal and external auditors. Their findings showed that AC's effectiveness is conditioned by the informal networks that exist between $\mathrm{AC}$ and other stakeholders. Finally, Beasley et al. (2009) investigated whether ACs provided substantive oversight of financial reporting or whether they play a role primarily a ceremonial role. Their findings show that ACs perceived themselves as engaging in effective monitoring of the financial reporting process, but there were variations in AC responses based on personal and company attributes (e.g., accounting expertise, regulation (SOX)).

Whereas the above studies on AC process and stakeholder perception focused on developed country setting, Al-Moataz (2003) extended the work to a developing country and surveyed ACs, and auditors in Saudi Arabia and found that ACs were perceived as of little benefit. Similarly, Jun Lin et al. (2008), in the Chinese context, found that ACs were perceived as ceremonial. Qasim (2018) conducted a questionnaire survey of ACs, external auditors, academics and regulators to garner their views about the important factors that enhance the effectiveness of the ACs in the UAE. The study found that AC independence was the most important among others, including the number of AC meetings, financial expertise, and size of ACs.

To sum up, the literature on the $A C$ has taken two lines of enquiry involving (1) examining the AC inputs-outputs relationship and (2) investigating the process and firmlevel factors perceived to affect the AC effectiveness. However, while this literature 
provides important insights, more studies are needed for three reasons. First, with the exception of Cohen et al. (2002; 2004), the existing studies as discussed above do not investigate the effects of institutional factors, such as the legal and regulatory environment and government intervention, on ACE. Yet, it is suggested that these are important factors of corporate governance effectiveness (e.g., Aguilera and Jackson, 2003; Gerged et al., 2021a; Gerged and Elheddad, 2020; Gerged et al., 2021c). Consistent with this, Cohen et al. $(2002 ; 2004)$ find the auditors perceived ACs of nonfinancial firms as powerful and effective in the post-SOX but weak and ineffective in the pre-SOX period.

Second, the prior studies have focused on the developed countries, with very limited attention on developing countries, where institutional frameworks are generally weak (see Boubakri et al., 2005; Mangena and Tauringana, 2007). Finally, and most importantly for our study, with the exception of Barakat and Hussainey (2013) and Sun and Liu (2014), who examine risk reporting and risk-taking effects of ACs, respectively, we are unaware of studies investigating stakeholders' perception of factors influencing ACE in the banking sector. Thus, our study builds and extends prior literature by investigating ACs and stakeholders' views, not only on AC effectiveness but also on both firm-level factors (see Ghafran and O'Sullivan, 2013) and national-level factors (Cohen et al., 2002; 2004) affecting the work of ACs in the banking sector in Libya. We also extend Masli et al. (2019), who examined the role of ACs in the Libyan banking sector, but not the factors enhancing and/or inhibiting their effectiveness. The Libyan banking sector is interesting to examine because $C G$ in general, and $A C s$ in particular, are recent phenomena. Moreover, the institutional framework supporting CG is, according to Masli (2018), the weakest in Africa and presents challenges on ACE. 


\section{Theory and hypotheses \\ 4.1 Theoretical considerations}

Although there are several theories of corporate governance practice, our conceptualisation of the factors influencing the effectiveness of the AC in the Libyan banking sector is underpinned by the agency theory and institutional theory. From the agency theory perspective (Jensen and Meckling, 1976; Fama and Jensen, 1983), the AC is seen as an important mechanism for reducing agency problems and preventing managers' opportunistic behaviour (Mangena and Chamisa, 2008; Beasley et al., 2009; Mangena and Pike, 2005). In this context, the quality of AC and its effectiveness in monitoring management depend on its structural attributes and resources such as AC size, independence, and diligence. Consequently, both the academic literature (e.g. Beasley and Salterio, 2001; DeZoort et al., 2002; Carcello and Neal, 2003; Mangena and Pike, 2005; Mangena and Chamisa, 2008) and corporate governance committees across the world (e.g., Blue Ribbon Committee, 1999; Smith Committee, 2003) emphasise these factors as apposite for the AC. In a similar vein, the Libyan CG Code (2010) also recognises the importance of these factors for a well-functioning $A C$ to assist the board of directors in monitoring managers' behaviour and to protect the interests of shareholders in the banking sector (Masli, 2018).

Whereas the agency theory provides an understanding of corporate governance effectiveness in the context of the quality of firm-level factors, the institutional theory (IT) (Di Maggio and Powell, 1983; Scott, 1987) takes a national view of the factors that impact the effectiveness of corporate governance mechanisms. Under this view, organisations are embedded in the country's system of political, legal, financial, educational and economic institutions (Di Maggio and Powell, 1983; La Porta et al., 1998). These contextual factors shape the national business systems (Matten and Moon, 2008; Jackson 
and Apostolakou, 2010; Gerged et al., 2021b) and exert coercive, normative or mimetic pressure on organisations (in our case, banks) to adopt certain structures or practices. ${ }^{1}$ Neglecting the mimetic (industry) pressure, we submit, as do La Porta et al. (1998) and Burdon and Sorour (2020), that the strength of coercive pressure (legal and regulatory systems; government intervention) and normative pressure (professional bodies' guidelines) will determine the extent to which firm corporate governance mechanisms, including ACs, function effectively to protect stakeholder interests. In this context, we postulate that if stakeholders perceive these institutional pressures as strong (weak) and effective (ineffective), they are also likely (less likely) to perceive the ACs established as effective (ineffective). Our reasoning is that the effectiveness of corporate governance, and the $\mathrm{AC}$, is an artefact of the quality of institutional framework supporting their establishment. In other words, the AC matters when that institutional framework that promotes its establishment and operation enables it to function effectively.

\subsection{Hypotheses Development}

As noted in the preceding section, stakeholder perception of the effectiveness of ACs must be dependent on their judgement of the quality of firm-level and institutional factors. We examine a number of these factors. DeZoort et al. (2002) argue that the authority afforded the ACs is an important factor. Drawing from both agency and institutional theories, AC authority is a function of its responsibilities and influence and derives from the board of directors, the country's legal and regulatory systems and corporate governance framework. In this regard, the strength of the board of directors (Beasley and Salterio, 2001; Raghunandan and Rama, 2007; Sharma et al., 2009) and the clarity of legal

\footnotetext{
${ }^{1}$ According to Di Maggio and Coercive pressure or isomorphism imply that organisations are pressured by a country's rules, laws or norms (e.g., the requirements of the $\mathrm{CBL}$ ) to adopt certain structures and practices; normative pressure or isomorphism depicts the effects of professional pronouncements (e.g., the recommendations of the LCGC, accounting standards) on practices, and mimetic pressure or isomorphism implies that organisations copy practices of their peers (in same industry).
} 
requirements, as well as corporate governance requirements relating to $\mathrm{AC}$ responsibilities and influence (La Porta et al., 1998; Lin et al., 2008; Saad et al., 2006), would affect its effectiveness. These facilitate the strength of AC's authority in that they support its engagements with managers, external and internal auditors, all key participants in its monitoring role. For instance, strong audit standards and corporate governance requirements (e.g. Sarbanes-Oxley Act, 2002; UK Corporate Governance Code, 2018) provide ACs with great authority as they require internal and external auditors to communicate with ACs on governance issues and making them more effective. In the Libyan banking sector, the authority of ACs derives from the CBL-CGC (2010), which requires $\mathrm{ACs}$ to communicate with managers and external auditors (see also Zagoub, 2017; Masli, 2018). This authority allows ACs to effectively support internal and external auditors in dealings with managers, thereby improving ACs' access to the relevant information from all levels of the management and facilitating its monitor function (DeZoort et al., 2002). To the extent that authority is an important attribute of the AC, we expect stakeholder perception of AC effectiveness to be influenced by their judgement of the strength of its authority. Thus:

H1: Stakeholder perception of AC effectiveness in the Libyan banking sector is related to their judgement about its authority.

The financial expertise of ACs has been popularised as an important factor for their effectiveness (see DeZoort et al., 2002; McDaniel et al., 2002; Mangena and Pike, 2005; Ho et al., 2014). The notion of AC financial expertise is underpinned by the rationale that committee members deal with complex financial matters, including technical auditing and financial reporting matters. In this regard, financial knowledge is viewed as improving their ability to identify and ask questions that 'make management think harder and auditors dig deeper' (Levitt, 2000). Thus, Mangena and Pike (2005) contend that the lack of expertise 
in the audit committee can lead to its oversight role being discounted by auditors and management; and hence undermining its monitoring role. Consequently, corporate governance codes (e.g., UK Corporate Governance Code, 2018) have proposed that some audit committee members should have accounting or related financial management expertise. Similarly, the professional accounting bodies in Libya, such as the Libyan Certified and Public Accountants Union (LCPAU), have recommended that the ACs in banks include at least one member with financial expertise (Masli, 2018). However, the challenge in many developing countries, including Libya, is that the market for qualified directors is limited (Mangena and Chamisa, 2008). Given this, ACs may lack the appropriate expertise to deal with complex financial matters. Thus:

H2: Stakeholder perception of AC effectiveness in the Libyan banking sector is related to their judgement about its financial expertise.

There is a general consensus in the agency theory-based literature that the independence of the board directors and the AC is critical in monitoring organisational outcomes (Mangena and Pike, 2005; Lin et al., 2006; Beasley et al., 2009). From an agency theory perspective, AC independence promotes its objectivity in making judgements that enhance stakeholders' interests (Rainsbury et al., 2008; Rezaee, 2009). One reason for this is that when members are independent, there is less potential for conflicts of interest, and therefore, more effective monitoring of opportunistic management (Klein, 2002). This is because independent members are perceived as free from managerial pressure and other external influences; thus, they are likely to act in the stakeholders' best interests (Reddy et al., 2015; Sanjaya, 2016). However, Mangena and Chamisa (2008) argue that the institutional setting in many developing countries lacks a viable market for directorship, thus creating impediments for the recruitment of independent directors. In support of this, Masli (2018) shows that potential independent 
AC members are both poorly qualified and experienced and poorly compensated. Compensation has been documented in prior literature (e.g., Engel et al., 2010; Kim and Suk, 2012) as providing the incentive for independent directors to monitor more effectively as they do not depend on managers for their livelihood. Thus:

H3: Stakeholder perception of AC effectiveness in the Libyan banking sector is related to their judgement about its independence.

The reviews of the literature by DeZoort et al. (2002) and Ghafran and O'Sullivan (2013) document that effective oversight of the $A C$ is contingent upon the resources available to the committee. These resources include access to management, external and internal auditors, legal counsel, and, more importantly, a sufficient number of members to allow substantive discussion and consideration of relevant issues. In the literature, the number of board members constituting the $\mathrm{AC}(\mathrm{AC}$ size) has dominated the $\mathrm{AC}$ resources debate (see DeZoort et al., 2002; Ghafran and O'Sullivan, 2013; Albring et al., 2014; Pucheta-Martínez et al., 2014). Most corporate governance codes (e.g., UK Corporate Governance Code, 2018) recommend a minimum of three members and providing sufficient resources to allow AC engagement with oversight duties. Thus:

H4: Stakeholder perception of AC effectiveness in the Libyan banking sector is related to their judgement about its size.

The literature emphasises diligence as potentially the most important factor in the effectiveness of ACs in monitoring and serving stakeholders' interests (see DeZoort et al., 2002; Sharma et al., 2009; Thiruvadi, 2012; Ghafran and O'Sullivan, 2013). Kalbers and Fogarty (1998) and DeZoort et al. (2002) define diligence as referring to the willingness of AC members to commit to engaging with the firm's corporate governance processes actively. Such commitment can be judged in the way they 'prepare, ask questions, and pursue answers when dealing with management, external auditors, internal auditors, and 
other relevant constituents (DeZoort et al., 2002, page 45). In the literature, AC diligence is observable from the frequency of audit committee meetings. Indeed regulatory bodies and researchers alike have argued that if ACs perform their responsibilities and duties effectively, they must meet regularly (Smith Committee, 2003; Krishnan, 2005; Burke et al., 2008). The frequency of meetings is believed to allow the committee to identify problems and take corrective actions promptly (Ebrahim, 2007). The LCGC of 2010 recommends ACs' members to meet at least once every three months. Thus the fifth hypothesis to test is:

H5: Stakeholder perception of AC effectiveness in the Libyan banking sector is related to their judgement about its diligence.

Thus far, the factors we have discussed are firm-level governance factors. However, from the viewpoint of IT, the effectiveness of firm-level governance factors is contingent upon the institutional setting of a country (Di Maggio and Powell, 1983; La Porta et al., 1998; Matten and Moon, 2008). Consequently, we discuss three institutional factors that can either enable or inhibit the AC's effectiveness. La Porta et al. (1998) point to the importance of the legal and regulatory system for corporate governance quality. They argue that the legal system determines the quality of corporate governance structures and facilitates the effectiveness of the governance structures in protecting the rights of investors or shareholders. In this case, on the one hand, it can be argued that a strong legal system means 'active and well-functioning courts can step in and rescue investors from abuse by management' (La Porta et al., 1998, p. 1140), providing the AC with the authority and the incentive to monitor and act on any abuse by managers. On the other hand, a weak legal system fails to provide ACs with adequate authority and incentives to monitor, particularly if the prosecution of fraudulent actions is unlikely. The empirical evidence shows the importance of the legal and regulatory systems on governance. For 
example, Cohen $(2002,2004)$ find that ACs were perceived as effective after the introduction of SOX. Mangena et al. (2012) find that the impact of corporate governance structures on firm performance is a function of the quality of the rule of law. Thus, to the extent that the legal and regulatory system in a country facilitates the role of governance structures, stakeholder perception of AC effectiveness will be contingent upon their judgment of the legal system's quality. In the context of Africa, Nganga (2003) argues that while there are CG frameworks, the weak and ineffective judicial system makes enforcement difficult. With specific reference to Libya, Abdou (2015) argues that the legal system is ineffective, and the CG framework is both inappropriate and flawed. Thus:

H6: Stakeholder perception of AC effectiveness in the Libyan banking sector is related to their judgment of legal and regulatory systems' quality.

The role of the government in how firms in a country are governed affects the effectiveness of corporate governance structures, including ACs. Based on the perspective of the IT, the government, as a product of the political system, is particularly important because it drives policy and the laws, including how these laws are enforced, and therefore determines the protection afforded investors (La Porta et al., 1998; Matten and Moon, 2008; Jackson and Apostolakou, 2010). Given this, La Porta et al. (1998) argue that corporate governance systems matter when the government enables the laws that protect shareholder rights to be enforced. In Africa, in general, the government can sometimes be an impediment to effective corporate governance. In relation to this, Okeahalam (2004) and Mangena and Chamisa (2008) point to the rife corruption in most African governments, including the meddling in corporate affairs. Mangena et al. (2012) provide evidence on how meddling in corporate affairs by corrupt government officials increases agency problems affecting performance. This implies that the quality of the government can either enhance or reduce the effectiveness of corporate governance structures. In the context of Libya, 
the role of the government in corporate affairs can be magnified because it is sometimes the controlling shareholder in many of the country's corporations, including the banking sector (Masli, 2018). In this context, there is a high degree of government intervention in the banking sector (Wu and Patel, 2015) and often at the expense of other shareholders (Larbsh, 2010; Abdou, 2015). Such interventions constrain the effectiveness of ACs in their monitoring role. Thus:

H7: Stakeholder perception of AC effectiveness in the Libyan banking sector is related to their judgement of the effects of government intervention.

Finally, drawing from the institutional theory, Wu and Patel (2015) identify the accounting system as an important factor in the efficient functioning of corporate governance in a country. Not only does the accounting system provide information about the company to stakeholders, but it is also used as a source of information by the board of directors, including AC members, in monitoring managers (Healy and Palepu, 2001; Armstrong et al., 2010). Thus, if the accounting system is weak, ACs and other stakeholders' ability to monitor managers is also compromised. Maatoug (2014) and Ahmad and Gao (2004) argue that the accounting system in Libya is relatively underdeveloped, and El-Firjani et al. (2014) points out that the accounting profession is weak. The implication of this is that to the extent that the AC relies on the accounting system to monitor, the weak systems compromise the quality of its monitoring in the banking sector. Thus:

H8: Stakeholder perception of AC effectiveness in the Libyan banking sector is related to their judgement of the quality of the accounting environment.

\section{Data and Research Design}

\subsection{Sample and data collection methods}

Our aim in this study is to investigate stakeholder perception of the factors influencing the effectiveness of $A C$ in the Libyan banking sector. The data used in this paper were a 
part of a large-scale study that investigated the roles and practices of audit committees in the banking sector in Libya. The data were collected using a sequential explanatory mixedmethods approach to better understand the factors influencing AC effectiveness (Hussey and Hussey, 1997; Cresewll, 2003; Ivankova et al., 2006). Following Creswell (2003), in the first phase, we collected data using a closed-ended questionnaire survey in order to garner the perception of stakeholders on ACE. In the second phase, we conducted semistructured interviews with a selected number of stakeholders to understand better the factors considered important or unimportant in the questionnaire survey.

Our sample consisted of five groups of stakeholders comprising members of the board of directors, AC members, executive managers, internal auditors and external auditors. These stakeholder groups were selected because they are considered critical in corporate governance in general and to the well-functioning of the $A C$ in particular (see also Cohen et al., 2002; Beasley et al., 2009; Abbott et al., 2010). Following an intensive search on the websites of Libyan banks based in Tripoli (the capital of the country) and telephone conversations with the Central Bank of Libya officials, we identified 400 stakeholders to which our questionnaire was distributed. In Table 1, we summarise the sample of stakeholders used in the questionnaire survey.

\section{[Insert Table 1 about here]}

As can be observed in Panel $A$, the questionnaires were sent to 64 members of the board of directors, 48 AC members, 112 executive managers, 112 internal auditors and 64 external auditors who were connected to the Libyan banking sector. In total, 218 completed questionnaires were collected, and the responses by each group are shown in Panel A. In Panel B of Table 1, we present the profile of the respondents in terms of education level, discipline and working experience. The respondents are highly qualified people with substantial experience in the banking sector. Thus, we are reasonably assured 
that our respondents are appropriate and the responses they give can be relied upon. The questionnaire was self-distributed and collected by one of the researchers. In relation to interviews, we selected 20 out of the 218 respondents (see Section 5.3 for details). The same researcher who self-administered the questionnaire also conducted semi-structured interviews.

\subsection{Questionnaire survey}

As already noted above, all our measures were constructed from a questionnaire survey which was developed from an extensive review of the AC literature (e.g. DeZoort et al., 2002; Bedard et al., 2004; Turley and Zaman, 2014; Lin et al., 2008; Beasley et al., 2009; Sharma et al., 2009), but taking account of the relevance to the Libyan context. These measures are defined in Table 2.

\section{[Insert Table 2 about here]}

ACs' effectiveness (ACE) measures were based on stakeholders' perception of statements on how ACs in the Libyan banking sector perform their roles. Following the literature, stakeholder perception of AC effectiveness was constructed from statements of three core roles of the $\mathrm{AC}$. The three roles are: (i) reviewing financial statements (4 statements), (ii) engagement with internal auditors (8 statements) and (iii) engagement with external auditors (5 statements). The stakeholders (respondents) were asked to indicate the extent to which they agreed with each of the statements relating to each of the roles on the basis of a 5-point Likert scale ranging from 1 (strongly disagree) to 5 (strongly agree) in relation to their bank's audit committee. We then constructed a composite measure of $A C E$. A higher rating implies ACE is perceived as high (and vice versa).

In relation to the factors, stakeholder perception was sought on eight factors identified in the literature as important for the effectiveness of corporate governance in general and $A C$ in particular. Similar to $A C$ effectiveness, the stakeholders were asked to 
indicate the extent to which they agreed with the statements on a 5-point Likert scale. Based on the Libyan literature (e.g., Abernathy et al., 2014; Abdou, 2015), the factors were categorised into firm-level factors (those that are within the firm's decision-control) and national-level factors (those that are outside the firm's decision-control). The firm-level factors are Authority (4 statements), Financial Expertise (1 statement), Independence (2 statements), Resources (1 statement) and Diligence (2 statements) (See Table 2). The statements on firm-level factors were designed positively; for instance, 'the AC has an adequate influence to carry out its roles'. A higher score indicates that stakeholders perceive the factor as enabling AC effectiveness in the Libyan banking sector. Nationallevel factors in the study are the Legal and regulatory environment (1 statement), Government intervention (1 statement) and Accounting and auditing environment (1 statement). In line with the Libyan literature, which suggests weaknesses in the institutional environment (e.g., Gerged and Almontaser, 2021; Abernathy et al., 2014; Abdou, 2015), the statements on national-level factors were designed in the negative direction, for instance, 'weakness of the accounting and auditing profession inhibit AC effectiveness'. A higher score indicates that stakeholders agree that the factor constraints $A C$ effectiveness in the Libyan banking sector. In both the AC effectiveness and factors, where the measures constructed are based on two or more statements, the Cronbach's Alpha was employed to test reliability, and in all cases, the coefficient was above the 0.7 benchmarks (e.g., Black et al., 2017; Ararat et al., 2017; Rae et al., 2017; Zahoor and Gerged, 2021). Prior to self-administering the questionnaire, we piloted it by surveying 59 respondents, including 17 executive managers, 16 internal auditors, 13 external auditors, 7 AC members and 6 board members. The outcome of the pilot tests indicated that the questions were appropriate for use. In respect of the biases on responses, we did not undertake any tests on this, given that questionnaires were self-administered. 


\subsection{Semi-structured interviews}

The semi-structured interviews were conducted following the questionnaire survey analysis and were intended to better understand the quantitative findings. Twenty semistructured interviews were conducted with stakeholders drawn from the same five groups who participated in the questionnaire survey. This amounted to four participants from each stakeholder group being interviewed (for further details, see Panel C of Table 1). The interviews explored the same questions as the questionnaire survey with a view to understanding the results of the questionnaire better. However, these were open- rather than close-ended, allowing for better and additional insights to be generated and understanding the questionnaire survey and modelling results.

\section{Empirical Results}

\subsection{Stakeholder perception of AC effectiveness and related factors}

First, in Table 3, we present the summary descriptive statistics of stakeholder perception of $A C$ effectiveness and the factors affecting $A C E$. It also shows whether there are any differences in perception among the five groups based on the Kruskal-Wallis tests. Panel A indicates the stakeholder perception of AC effectiveness and shows the overall mean effectiveness as well as the means of the three AC roles. Panel B presents the mean perception of the factors influencing AC effectiveness.

\section{[Insert Table 3 about here]}

In Panel A, the overall AC effectiveness has a mean (median) rating of 3.68 (4.00), suggesting that stakeholder groups perceive ACs in the Libyan banking sector as generally effective in their roles. The board directors, AC members, and external auditors perceive AC effectiveness to be higher than executive managers and internal auditors. Concerning the individual roles, ACs are viewed as more effective in engagement with internal auditors [mean (median) of $3.75(4.00)$ ] and reviewing financial statements [mean (median) of 3.68 $(4.00)]$ than engagement with external auditors [mean (median) of $3.34(3.00)]$. We find 
that there are no significant differences in perception among the five stakeholder groups based on the Kruskal-Wallis tests except for reviewing financial statements. The differences in perception relating to reviewing financial statements appear to be mainly driven by the perceptions of the AC members themselves and executive managers who seem to view $A C$ effectiveness as lower than others. Overall, it appears that there is a general agreement among the stakeholders that the AC in the Libyan banking sector is effective in performing its roles.

In relation to the factors influencing $\mathrm{AC}$ effectiveness, Table 3, Panel B, indicates that stakeholders agree that both firm-level and national-level factors contribute to AC effectiveness in the Libyan banking sector. First, focusing on firm-level factors, AC financial expertise was rated highly by stakeholders [mean (median) of 4.09 (4.00)]. This suggests that the stakeholders perceive ACs in the banking sector as having sufficient members with relevant and appropriate financial expertise to deal with financial and auditing matters associated with the sector. Similarly, although lower than financial expertise, AC resources [mean (median) of $3.64(4.00)$ ], AC authority [mean (median) of $3.56(4.00)$ ] and AC diligence [mean (median) of $3.52(4.00)$ ] are also viewed as generally high and contributing to ACE in the Libyan banking sector. However, AC independence is rated lower than the other factors [mean (median) of $3.37(3.00)$ ]. The median rating of 3.00 suggests that most stakeholders perceive ACs in the Libyan banking sector as lacking sufficient independence to be effective in their roles.

On the whole, except for financial expertise and AC independence, the Kruskal-Wallis tests show that there are no significant differences in perception among the stakeholders about the attributes of ACs and their effects on ACE in the Libyan banking sector. The perceived differences in financial expertise are driven by the ratings of the executive managers and internal auditors that, although high, are lower than the other stakeholders. 
We also observe that differences in perceived $A C$ independence derive from $A C$ members and external auditors who appear to attach higher ratings for this factor.

With regard to the national-level factors, Panel $\mathrm{C}$ shows that stakeholders perceive the weak legal and regulatory environment [mean (median) of 3.92 (4.00)] government intervention [mean (median) of $3.70(4.00)$ ] as the most constraining factors of $A C$ effectiveness in the banking sector. In particular, external auditors, AC members, board members, and executive managers strongly agreed that weaknesses in the legal and regulatory environment negatively impact ACE. Although lower than the legal and regulatory environment and government intervention, stakeholders also agree that weaknesses in the Libyan accounting and auditing environment [mean (median) of 3.41 (4.00)] are also an impediment to AC effectiveness. The Kruskal-Wallis tests show that, except for the legal and regulatory environment, there is a general agreement among stakeholders as to the effects of the national-level factors. Differences appear to exist in particular between internal auditors and the other groups in terms of the negative effects of the legal and regulatory environment.

\subsection{Factors influencing AC effectiveness-A multivariate setting}

The results from analysing the questionnaire responses demonstrate that stakeholders perceive ACs in the Libyan banking sector as having some level of effectiveness. Overall, the findings suggest that both the firm-level and national-level factors affect the effectiveness of the $A C$ in the banking sector. Whilst these results provide us with an understanding of the perceived effects of these factors individually, they do not tell us how, in combination, they affect perceived AC effectiveness. Thus, in this section, we extend the analyses by examining the relationship between the perceived measures of $A C$ effectiveness and the perceived factors in a multivariate setting. Our intention in this 
analysis is to understand what factors are important in stakeholders' perception of ACE in the banking sector in Libya.

\subsubsection{Model specification}

We specify the following ordinary least square regression model with control :

$A C E=\beta_{0}+\beta_{1} A C$ Authority $+\beta_{2} A C$ Financial Expertise $+\beta_{3} A C$ Independence $+\beta_{4} A C$ Resources $+\beta_{5} A C$ Diligence $+\beta_{3}$ Legal and Regulatory Environment $+\beta_{4}$ Government Intervention $+\beta_{5}$ Accounting and Auditing Environment $+\Sigma \beta_{k}$ Controls $+\varepsilon$

$A C E$ is perceived $A C$ effectiveness and is a composite measure constructed from averaging stakeholder perception of the three AC roles: a review of financial statements, engagement with internal and external auditors. In further analyses, we also run regressions for each individual component of $\mathrm{AC}$. It is possible that each component may be perceived as being influenced by a different set of factors. Controls are dummies capturing stakeholder group, education background and experience and are introduced in the regressions to control for the fact that the perception of $A C$ effectiveness may be an artefact of the stakeholder roles and background than the factors. Three stakeholder groups are created as follows: Stakeholder group 1 (1 if a board member, including AC members; 0 otherwise); Stakeholder group 2 (1 if executive manager; 0 otherwise); Stakeholder group 3 ( 1 if auditor, both internal and external; 0 otherwise). Education background is measured as one if the holder of a qualification in accounting or finance or economics; 0 otherwise. Finally, the experience is measured as one if working experience in the role is more than five years; 0 otherwise. All other variables are as defined in Table 2.

\subsubsection{Regression results}

We start the regression analyses by assessing whether both the dependent variable and independent variables are normally distributed. Except for AC financial expertise and, Legal and regulatory environment, all the other variables violate normality assumptions. To address this, we follow Cooke (1998) and transform the variables using normal scores. 
Cooke (1998) suggests that the normal scores are effective in transforming datasets that violate normality assumptions. ${ }^{2}$ Next, we run correlations among the independent variables to assess whether there are any problems with multicollinearity. As reported in Table 4, the results show that the correlations among the independent variables are all way below the benchmark of 0.90 (see Greene, 2017). We also examined the variance inflation factors (VIFs), and all are below the benchmark 10 (Greene, 2017). These analyses suggest that multicollinearity is not a major problem in our models.

\section{[Insert Table 4 about here]}

In Table 5, we present the multivariate regression analysis. Model 1 of Table 5 shows the results of modelling overall ACE against its perceived determinants as measured from questionnaire responses. The results show that with respect to firm-level factors, authority, expertise and diligence are significantly associated with ACE at $5 \%$ level or better. Thus, $\mathrm{H} 1, \mathrm{H} 2$ and $\mathrm{H} 3$ are supported-ACE is related to stakeholder judgement of AC authority, expertise and diligence. However, AC independence and resources, whilst both positive, are insignificantly related to ACE. Therefore, $\mathrm{H} 3$ and $\mathrm{H} 4$ are both rejected. When we split ACE into component measures, the results show that authority is significantly related to engagement with the internal audit function and not to reviewing financial statements and engagement with the external auditing function. However, AC expertise and diligence have positive relationships with each of the individual components of $A C E$, whilst $A C$ independence and resources remain insignificant across the three ACE components.

In relation to national-level factors, Table 5 indicates that the weakness in the legal and regulatory environment is negatively related to overall ACE at the $1 \%$ level. Hence, H6 is accepted-perceived ACE depends upon stakeholder judgement of the legal and

\footnotetext{
2 We also transform the variables using the natural logarithms and re-run the regressions, and our results are maintained. In addition, we run the regression with the untransformed data, and the results are generally consistent. The results of these analyses are not tabulated in the paper, but can be availed if requested.
} 
regulatory environment. The relationship between government environment and overall ACE is negative but not significant; thus, $\mathrm{H} 7$ is rejected. In contrast, the accounting and auditing environment is positively related to ACE at a $1 \%$ level. We, therefore, accept $\mathrm{H} 8$. With regard to ACE components, our results show that the legal and regulatory environment and accounting and auditing environment are related to reviewing financial statements and engagement with the internal auditing function, but not the external auditing function. Government intervention is significantly and negatively related to reviewing financial reports only.

\section{[Insert Table 5 about here]}

To further understand the results in Table 5, we undertake additional analyses. In particular, Authority, Independence and Diligence are constructed from two or more items in the questionnaire. We, therefore, rerun our regressions, splitting these three factors into their items. Authority is split into influence, access to information, quality of board governance and, clarity of the specific legal and stock exchange rules supporting ACs. AC independence is split into the presence of sufficient non-executive directors, qualification and experience of $A C$ members and the adequacy of compensation of members. Finally, we split Diligence into meetings and, time and effort of the ACs. Our rationale for this analysis is to provide an understanding of which among the individual items may be driving the results. The results of these analyses are reported in Table 6.

\section{[Insert Table 6 about here]}

As can be observed in Table 6, with respect to AC Authority, only Influence is significant and positively related to ACE. Access to information, quality of board governance and clarity of legal and stock exchange rules supporting ACs are all not significant. This suggests that the positive relationship between Authority and perceived 
ACE, as shown in Table 5, is an artefact of the influence the AC is perceived to have by stakeholders. As for AC independence, whereas the presence of sufficient non-executive directors and the compensation of AC members are not significant, AC members' qualifications and experience are significantly related to ACE at the $10 \%$ level or better. Thus, stakeholders perceive qualification and experience as key factors in supporting the independence of ACs, and therefore, their effectiveness in the Libyan banking sector. Finally, for diligence, the results show that time and effort and the number of AC meetings are both significantly related to ACE. Thus, both elements of diligence are perceived as important for ACE.

\section{Discussion of findings}

In this study, we investigate the firm-level and national level factors perceived to influence the effectiveness of ACs in the Libyan banking sector. We structure our discussion in line with our classification of the factors influencing ACE.

\subsection{The impact of firm-level factors on ACE}

In relation to firm-level factors, the results show that the authority, financial expertise and diligence of $\mathrm{AC}$ members are perceived by stakeholders as generally high and the most enhancing factors of ACE in the Libyan banking sector. The importance of these factors is similarly confirmed in a multivariate setting, as they are shown to be positively and significantly related to ACE. On the whole, these results are consistent with prior agency theory-based $\mathrm{AC}$ literature suggesting, as well as documenting, the importance of these AC attributes for the quality of financial statements (see DeFond et al., 2005; Krishnan, 2005; Mangena and Chamisa, 2008; Ghafran and O'Sullivan, 2013; Ho et al., 2014; Maraghni and Nekhili, 2014). Although this prior literature focuses on nonfinancial firms, our paper's findings speak to the fact that $A C$ authority, financial expertise and 
diligence are equally perceived as critical for ACE in the banking sector and developing countries.

The semi-interviews with the selected stakeholders strongly support these findings. For instance, the interviews show general agreement that ACs in the banking sector have appropriate financial expertise. Emphasising the importance of appropriate qualifications, an AC Chairman commented that:

"The audit committee cannot carry out its tasks effectively unless its members are qualified and have sufficient experience in the banking industry." (AC Chairman No 1).

Thus, as suggested in prior studies, well-qualified audit committee members are more likely to understand better auditor judgements and discern the substance of any disagreements between management and external auditors (see Mangena and Pike, 2005; Raghunandan and Rama, 2007). One audit committee member confidently expressed the existence of well-qualified AC members (with financial expertise) in the Libyan banking sector:

"The members of the audit committee have sufficient accounting expertise. All the four $A C$ members in our bank come from an accounting background, and two of them have a PhD". (AC Member No 4).

This means that ACs in the Libyan banking sector have the requisite financial expertise to help them understand the operational complexities involved in the banking sector, and therefore, are able to monitor the financial reporting process effectively.

Similar views were expressed in respect of $A C$ authority and $A C$ diligence. With regard to authority, the interviewees suggested that ACs in the banking sector had the necessary authority to make effectiveness. For example, an AC member supporting the view that the $A C$ has authority pointed to the AC's ability to access the information it requires efficiently. Thus: 
"In general, the audit committee can easily access information, particularly through its oversight of the internal audit function". (AC Member No 2).

This view is clearly consistent with the high rating accorded the $\mathrm{AC}$ role of engagement with the internal audit function (see Section 6.1) and with professional bodies in Libya such as the LCPAU who have issued guidelines to help AC members better understand the authority granted to them in performing their roles (see Masli et al. 2019). Furthermore, in support of the authority viewpoint, a board member pointed out that in general, ACs have the authority, but also noted, however, that how such authority is exercised depends to some extent on who sits on the committee - such as, on whether the members are appropriately qualified and experienced. Thus:

"The audit committee has authority and influence enough to carry out their responsibilities, but the execution of this authority will depend on the composition of the audit committee". (Board Member BM No 1).

This speaks to the fact that whilst AC authority in the Libyan banking sector is present, it alone cannot necessarily be enough for ACE. Authority functions well by interacting with other factors such as financial expertise and independence. Mangena and Pike (2005) support this view, arguing that the ACE cannot be achieved by emphasising one AC attribute; instead, all attributes interact to enhance ACE in monitoring the financial reporting process. In line with the agency theory-based literature (see DeZoort et al., 2002; Krishnan, 2005; Sharma et al., 2009; Thiruvadi, 2012; Braswell et al., 2012; Hogan et al., 2014), our interviewees also emphasised the importance of AC diligence as an important factor and perceived ACs in the Libyan banking sector as performing their roles and responsibilities diligently. Most interviewees indicated that their audit committee's level of time and effort dedicates to its duties were adequate. As commented by one board chairman:

"I think that the time and effort spent, particularly the number of meetings by audit committee members, are clear and obvious. It has ten meetings a year, which exceeds 
the number of meetings required under the code of corporate governance, which is just four." (Board Chairman No 3).

Another interviewee, an AC Chairman agreed, but suggested that time and effort alone are not sufficient to enhance ACE unless they are supported by other attributes such as sufficient independence, expertise, resources and authority to 'make it more effective in performing its responsibilities and tasks'. This supports the view alluded to earlier that AC attributes interact to enhance ACE.

Interestingly, despite being rated highly by stakeholders, AC resources (measured in $A C$ size) are not significantly related to ACE's judgment in the regressions. Similarly, the regression results suggest that stakeholders' perception of ACE in the banking sector is not related to their $A C$ independence judgment. These results suggest that whilst stakeholders consider these as important, they do not consider them pre-requisites for their overall judgement of ACE in the Libyan banking sector. This, of course, is inconsistent with the agency theory view that $A C$ independence and size are important attributes for monitoring the financial reporting process (see Carcello and Neal, 2003; Mangena and Pike, 2005). One possible reason for this is that the market for qualified and experienced directors in developing countries, particularly in Africa, is limited (see Mangena and Chamisa, 2008). To the extent that this is the case, stakeholders may discount the importance of AC size and independence in making judgements about ACE. In support of this, the results in Table 5 show that directors' poor qualification and experience in the banking sector is an impediment to AC perceived independence. However, we note that some prior studies examining the relationship between these attributes and financial reporting quality have also reported insignificant results in the context of developed countries (e.g., Krishnan, 2005; Mangena and Chamisa, 2008). In an effort to gain more insights about this result, one of the interviewees (i.e., external auditor) expressed his 
serious concerns regarding the independence of ACs in Libya, which is expected, from his own view, to diminish its contribution to ACE. Specifically, he stated that:

"The selection process for the audit committee members is often inadequate, and I think that they are not completely independent". (External auditor No 1).

\subsection{Impact of national-level factors on ACE}

The survey results indicate that national-level factors are perceived as impediments to the effectiveness of the AC in the Libyan banking sector. As can be seen in Table 3, Panel C, most stakeholders agreed with the statement that the weak legal and regulatory environment, intervention by the government and weakness in the accounting and auditing environment are key obstacles to ACE. These findings are confirmed in the regression analysis and are consistent with the institutional theory view that the institutional structures supporting corporate governance have important implications for ACE (see La Porta et al., 1998; Matten and Moon, 2008; Beasley et al., 2009).

In $\mathrm{H} 6$, we posited that stakeholder perception of ACE is a function of how they view the quality of the legal and regulatory system. We suggested, in line with the IT (La Porta et al., 1998; Matten and Moon, 2008; Jackson and Apostolakou, 2010), that a well-functioning legal and regulatory system will act as a coercive force, not only for the establishment of ACs but also for enhancing their authority and incentive to monitor effectively. To the extent that stakeholders perceive the legal and regulatory system as supporting the work of the AC, they are to perceive the $A C$ as effective. We find that stakeholders perceive weakness in the legal and regulatory environment as a major impediment to ACE. This finding is supported by the regression analysis, which shows that the legal and regulatory environment is strongly and negatively related to stakeholder judgement of ACE in the banking sector. The impact of this factor was particularly emphasised in the semi- 
structured interviews with most interviewees, suggesting it is a critical factor impacting corporate governance and ACE in the banking sector. A board member commented:

"This factor [legal and regulatory environment] is actually an influential factor. The current legislative environment in Libya is very weak; for example, laws are issued without examination of the impact of the legislation on business (including banks), and at the same time, certain aspects of the legislation of Libya's banks are either lacking or need improvement". (Board Member BM No 3).

Another interviewee, an AC Chairman, was also critical of the legal and regulatory environment in Libya. Thus:

"I think that the legal environment...has become an obstacle to the banking business and the work of the audit committee." (AC Chairman No 1).

These views are also supported by a general manager of one of the banks who pointed out that:

"I think that the legal and regulatory environment affects the committee's practice. The formation of the audit committee may be based on the Code of CG, but with no strong legal and regulatory backing, the committee's role may only become symbolic. This means that if these committees are being set up merely to gain legitimacy outside the organisation, their role may end up being symbolic, only." (Executive Manager EM No 1).

These sentiments are consistent with the current weak legal and regulatory environment (Abdou, 2015; Amaeshi et al., 2016; Gerged and Almontaser, 2021) as failing to facilitate ACE. They are also consistent with the findings of Cohen $(2002,2004)$ and Mangena et al. (2012) and the IT's viewpoint that an effective legal and regulatory system, acting as coercive pressure, is important for well-functioning corporate governance structures (see La Porta et al., 1998; Matten and Moon, 2008; Jackson and Apostolakou, 2010). This lack of coercive pressure, as depicted in the weaknesses in the legal and regulatory system, creating a non-enabling institutional environment and institutional voids (Gerged and Almontaser, 2021), implies that the existence of audit committees in Libyan banks may be symbolic (see also Beasley et al., 2009; Amaeshi et al., 2016). 
In line with $\mathrm{H} 7$, we also find that stakeholders perceived the intervention of the Libyan government in the banking sector as problematic for ACE. In support, the regressions also show that this factor is negatively related to ACE's ability to review financial statements. These findings suggest, consistent with the IT that the governments can either be an enhancement or an impediment of corporate governance (La Porta et al., 1998; Matten and Moon, 2008). In this case, government intervention is an impediment to ACE in the banking sector. This is consistent with other studies in Africa that show evidence suggesting that meddling in corporate affairs affect the effectiveness of corporate governance mechanisms (Mangena et al., 2012; Wu and Patel, 2015; Abdou, 2015). In this case, respondents were very critical about government intervention, sometimes as perpetrated mainly by the CBL. For example, a board chairman commented:

"There has been a lot of intervention in the work of the bank by the CBL in recent times. The CBL owns $80 \%$ of the bank, but this does not justify its interference in the affairs of the bank. Its role should be to regulate and supervise the activities of banks, and this intervention has an impact on the bank and its corporate governance". (Board chairman No 3).

A similar view was echoed by an AC chairman, particularly as it directly affects the audit committee. Thus:

"The intervention of government and the Central Bank in the work of the bank certainly affects the practices of the audit committee; as an integral part of the bank, any impact on the bank will also affect the audit committee". (AC chairman No 3).

Some of the interviewees expressed concern that government intervention in this sector extends to the appointment to senior positions such as board chairman with profound consequences for the board and $A C$ independence. An executive manager gave this example of government intervention:

"In my opinion, government intervention has an impact on bankings' businesses and corporate governance, including ACs, and it needs to be limited. For example, the 
government has forced us to allow a foreign investor to become a partner of the bank. This partner has a $19 \%$ share of the bank's stock, with the right to appoint the chairman of the board and the general manager." (Executive Manager EM No 3).

Finally, we also suggest in $\mathrm{H} 8$ that the quality of the accounting environment is an important factor of ACE. Our submission, driven by the IT (Matten and Moon, 2008; Jackson and Apostolakou, 2010; Wu and Patel, 2015), is that the accounting and auditing environment is important for a good function corporate governance system in a country (see also Healy and Palepu, 2001; Armstrong et al., 2010). Consistent with Burdon and Sorour (2020), our findings indicate that the pronouncements or guidelines of the accounting bodies are important normative pressures that influence the quality of information available for use by the AC. The extent to which these pronouncements and guidelines are perceived as functional will determine how the outcomes of the information system promote effective corporate governance. The findings show that stakeholders perceive weaknesses in Libya's accounting and auditing environment as affecting the quality of corporate governance and audit committees in the banking sector. The regression results also indicate a negative and significant relationship between the accounting and auditing environment and perceived ACE. These results suggest that the accounting environment is limited in its role of providing relevant and reliable information to help the AC function effectively. The important role of the accounting system is clearly put across by an audit committee chairman who indicates that having skilled accountants working for the bank facilitates the committee's oversight role:

".......when the accountants and auditors in the bank are more highly qualified, the audit committee's monitoring and oversight process is easier." (AC chairman No 3 ).

However, consistent with the questionnaire survey and regression results, interviewees expressed concerns about the state of the accounting and auditing profession 
in Libya and its implications for ACE in the banking sector. For instance, a chairman of an audit committee states that:

"The weakness of the accounting and auditing profession in Libya certainly affects the work of the audit committee. For example, sometimes the internal auditors produce very weak reports in terms of content because those auditors may lack the necessary qualifications". (AC chairman No 1).

The accounting and auditing profession's weaknesses in Libya have been alluded to in other studies (see Ahmad and Gao, 2004; Maatoug, 2014; El-Firjani et al., 2014). These findings are in line with the long-standing literature that suggests that the quality of the accounting system in a country is an important institutional mechanism for corporate governance quality (see Healy and Palepu, 2001; Wu and Patel, 2015). Our finding implies that the AC's ability to monitor the financial statements in the Libyan banking sector is compromised because of weaknesses in the accounting and auditing profession that are unable to provide high-quality information with the AC.

\section{Conclusion}

This study contributes to the extant CG literature by investigating and evaluating the firm-level and national-level factors that influence the effectiveness of ACs in emerging economies, with the particular case of the Libyan banking sector. Previous studies on ACE have been mostly limited to developed economies and nonfinancial firms. This study extends the AC literature to developing countries, focusing on the banking sector in Libya. Using a mixed-method approach that involves questionnaire survey and regression analysis, complemented by semi-structured interviews, we find that ACs in the Libyan banking sectors are perceived as effective in the roles. We argue that the effectiveness of ACs is a function of both firm-level and national level factors. In particular, stakeholders perceived ACE as dependent on AC authority, financial expertise, diligence, AC 
independence and resources. In relation to national level factors, we find that weaknesses in the legal and regulatory environment, government intervention and weaknesses in the accounting and auditing environment are perceived as impediments to ACE in the banking sector. Taken together, these findings demonstrate the importance of both firm-level and institutional factors in facilitating the effectiveness of corporate governance structures.

Our work has implications for the corporate governance literature and practice. In particular, we contribute to the literature on AC inputs and outputs (e.g., Raghunandan and Rama, 2007; Sharma et al., 2009; Ghafran and O'Sullivan, 2013) by investigating stakeholder perception of the impact of firm-level and national-level factors on ACE in a developing country. In this case, we demonstrate that factors such as authority, financial expertise, and diligence are important for ACE in all environments. We also extend the literature by examining ACs in the banking sector, where there is a paucity of studies. To this extent, we contribute and extend recent work by Barakat and Hussainey (2013) and Sun and Liu (2014) examining the risk reporting and risk-taking effects of ACs. We differ in that we survey stakeholders on the impact of both firm-level factors and national-level factors on ACE compared with prior studies that were limited to firm-level determinants of ACE. This provides more extensive empirical evidence on the drivers of ACE in a nonenabling institutional environment.

In relation to practice, our work has implications for regulators, policymakers and the banking sector. The findings suggest that firm-level factors such as, among others, AC authority, independence, resources, and expertise are important to indicate the need for the banking sector to reevaluate the quality of their ACs to improve their effectiveness. For example, the banking sector could consider whether their governance arrangements provide ACs with authority and resources to carry out their roles. With regards to regulators and policymakers, the findings that weaknesses in the legal and regulatory system and the 
intervention by government in the banking sector are impediments to corporate governance quality point to the need for a rethink about improvements in regulations and their enforcement mechanisms. This is particularly important given the country's drive to attract foreign investment. The accounting regulators or professional bodies need to strengthen the accounting and auditing environment to enhance the quality of information available to the boards of banks, including the ACs. For instance, they could work in partnership with the banking sector to develop training programmes relating to financial reporting in the sector. This will help to support accountants and auditors, thereby enhancing their ability to provide high-quality information. This is a crucial implication due to the importance of high-quality information in good corporate governance practices (see Armstrong et al., 2010).

However, whilst our findings are interesting and important, they have to be interpreted in the context of some limitations. For example, our sample of 218 completed questionnaires and only 20 interviews could be seen as limited. Also, the sampled banks have covered the Tripoli geographical region of Libya due to the political conflicts that the country is witnessing since 2011. Nevertheless, this provided us with a first step in understanding the factors influencing ACE in a developing country. Further studies, therefore, are recommended to replicate our study, including other regions in Libya. Additionally, our study is a sectorial investigation of the firm-level and national-level ACE determinants in the banking sector. Thus, future researchers can use our developed research instrument to examine ACE determinants across different sectors in Libya and other developing economies of a similar nature. 


\section{References}

Abbott, L. J., Daugherty, B., Parker, S., and Peters, G. F., 2016. Internal Audit Quality and Financial Reporting Quality: The joint importance of independence and competence. Journal of Accounting Research, 54(1), 3-40.

Abdou, M. A., 2015. Towards a New Solution of Minority Shareholder Protection in Libya: Letting the Minority Shareholders have a Voice. PhD. Thesis, University of Glasgow.

Abernathy, J. L., Beyer, B., Masli, A., and Stefaniak, C., 2014. The Association between Characteristics of Audit Committee Accounting Experts, Audit Committee Chairs, and Financial Reporting Timeliness. Advances in Accounting, 30(2), 283-297.

Aebi, V., Sabato, G. and Schmid, M., 2012. Risk management, corporate governance and bank performance in the financial crisis, Journal of Banking \& Finance, 36(12), 3213-3226

Aguilera, R. V., \& Jackson, G., 2003. The cross-national diversity of corporate governance: Dimensions and determinants. Academy of Management Review, 28(3), 447-465.

Ahmad, N. S., \& Gao, S. S., 2004. Changes, Problems and Challenges of Accounting Education in Libya. Accounting Education, 13(3), 365-390.

Albitar, K., Hussainey, K., Kolade, N., \& Gerged, A. M. (2020). ESG disclosure and firm performance before and after IR: The moderating role of governance mechanisms. International Journal of Accounting \& Information Management, 28(3), 429444.

Albring, S., Robinson, D., \& Robinson, M., 2014. Audit Committee Financial Expertise, Corporate Governance, and the Voluntary Switch from Auditor-Provided to Non-Auditor-Provided Tax Services. Advances in Accounting, 30(1), 81-94.

Al-Moataz, E. S., 2003. The effectiveness of audit committees within Saudi corporations. PhD thesis, Loughborough University.

Amaeshi, K., Adegbite, E., \& Rajwani, T., 2016. Corporate social responsibility in challenging and non-enabling institutional contexts: Do institutional voids matter?. Journal of Business Ethics, 134(1), 135-153.

Ararat, M., Black, B. S., \& Yurtoglu, B. B., 2017. The effect of corporate governance on firm value and profitability: Time-series evidence from Turkey. Emerging Markets Review, 30, 113-132.

Armstrong, C.S., Guay, W.R. and Weber, J.P (2010). The role of information and financial reporting in corporate governance and debt contracting, Journal of Accounting and Economics, 50, 179-234.

Barakat, A. \& Hussainey, K., 2013. Bank governance, regulation, supervision, and risk-taking reporting: Evidence from operational risk disclosures in European banks. International Review of Financial Analysis, 30, 254-273

Baxter, P., 2010. Factors associated with the quality of audit committees. Pacific Accounting Review, 22(1), 57-74.

Beasley, M. S., \& Salterio, S. E., 2001. The relationship between board characteristics and voluntary improvements in audit committee composition and experience. Contemporary Accounting Research, 18(4), 539-570.

Beasley, M. S., Carcello, J. V., Hermanson, D. R., \& Neal, T. L., 2009. The audit committee oversight process. Contemporary Accounting Research, 26(1), 65-122.

Bédard, J., \& Gendron, Y., 2010. Strengthening the financial reporting system: Can audit committees deliver? International Journal of Auditing, 14(2), 174-210.

Bedard, J., Chtourou, S. M., \& Courteau, L., 2004. The effect of audit committee expertise, independence, and activity on aggressive earnings management. Auditing: A Journal of Practice \& Theory, 23(2), 13-35.

Black, B., De Carvalho, A. G., Khanna, V., Kim, W., \& Yurtoglu, B., 2017. Corporate governance indices and construct validity. Corporate Governance: An International Review, 25(6), 397410.

Blue Ribbon Committee on Improving the Effectiveness of Corporate Audit Committees., 1999. Report and recommendations of the blue ribbon committee on improving the effectiveness 
of corporate audit committees. New York: New York Stock Exchange and National Association of Securities Dealers.

Boubakri, N., Cosset, J., \& Guedhami, O., 2005. Liberalization, corporate governance and the performance of privatized firms in developing countries. Journal of Corporate Finance, 11(5), 767-790.

Burdon, W. M., \& Sorour, M. K., 2020. Institutional theory and evolution of 'a legitimate compliance culture: the case of the UK financial service sector. Journal of Business Ethics, 162(1), 4780.

Burke, F. M., Guy, D. M., \& Tatum, K. W., 2008. Audit committees: A guide for directors, management, and consultants. 5th ed. Chicago, USA: $\mathrm{CCH}$.

Carcello, J. V., \& Neal, T. L., 2003. Audit committee characteristics and auditor dismissals following "new" going-concern reports. The Accounting Review, 78(1), 95-117.

Central Bank of Libya (CBL), 2008. The 52nd Report of the Central Bank of Libya, Tripoli, Libya.

Central Bank of Libya (CBL), 2010a. Code of Corporate Governance for Libyan Banks. Tripoli, Libya.

Central Bank of Libya (CBL), 2010b. Executive Position for Monetary and Banking Policy - During the Period 2002- 2010. Tripoli, Libya.

Central Bank of Libya (CBL), 2013. The 57th Report of the Central Bank of Libya, Tripoli, Libya.

Central Bank of Libya (CBL), 2016. Development of the most important financial data and indicators for Libyan commercial banks (2008 - 2nd quarter). Tripoli, Libya.

Chanda, S., Burton, B. and Dunne, T., 2017. The nature and potential of corporate governance in developing countries: Zambian perceptions. Accounting, Auditing \& Accountability Journal, 30(6), 1257-1287.

Cohen, J., Krishnamoorthy, G., \& Wright, A. M., 2002. Corporate governance and the audit process. Contemporary Accounting Research, 19(4), 573-594.

Cohen, J.R., Krishnamoorthy, G. and Wright, A., 2004. The corporate governance mosaic and financial reporting quality. Journal of Accounting Literature, 87-152.

Cooke, T. E., 1998. Regression analysis in accounting disclosure studies, Accounting and Business Research, 28(3), 209-224.

Creswell, J. W., 2003. A framework for design. Research design: Qualitative, quantitative, and mixed methods approach, 9-11.

DeFond, M. L., Hann, R. N., \& Hu, X., 2005. Does the market value financial expertise on audit committees of boards of directors? Journal of Accounting Research, 43(2), 153-193.

Dermine, J., 2013. Bank corporate governance, beyond the global banking crisis, Financial Markets, Institutions \& Instruments, 22(5), 259-281

DeZoort, F. T., Hermanson, D. R., Archambeault, D. S., \& Reed, S. A., 2002. Audit committee effectiveness: A synthesis of the empirical audit committee literature. Journal of Accounting Literature, 21, 2002, 38-75.

Di Maggio, P. J., \& Powell, W. W., 1983. The iron cage revisited: Institutional isomorphism and collective rationality in organizational fields. American Sociological Review, 147-160.

Ebrahim, A., 2007. Earnings management and board activity: Additional evidence. Review of Accounting and Finance, 6(1), 42-58.

El-Firjani, E., Menacere, K., \& Pegum, R., 2014. Developing corporate accounting regulation in Libya past and future challenges. Journal of Accounting in Emerging Economies, 4(1), 2256.

Elsakit, O. M., 2017. Influences on the development of the Libyan banking sector. IOSR Journal of Business and Management, 19(11), 60-73.

Engel, E., Hayes, R. M., \& Wang, X., 2010. Audit committee compensation and the demand for monitoring of the financial reporting process. Journal of Accounting and Economics, 49(1), 136-154.

Fama, E. F., \& Jensen, M. C., 1983. Separation of ownership and control. Journal of Law and Economics, 26(2), 301-325.

Fearnley, S., \& Beattie, V., 2004. The reform of the UK's auditor independence framework after the Enron collapse: An example of Evidence-based policymaking. International Journal of Auditing, 8(2), 117-138. 
Fichtner, J. R., 2010. The recent international growth of mandatory audit committee requirements. International Journal of Disclosure and Governance, 7(3), 227-243.

FRC., 2018. The UK corporate governance code. London: Financial Reporting Council.

Gendron, Y. and Bedard, J., 2006. On the constitution of audit committee effectiveness, Accounting, Organizations and Society, 31(3), 211-239.

Gerged, A. M., 2021. Factors affecting corporate environmental disclosure in emerging markets: The role of corporate governance structures. Business Strategy and the Environment, 30(1), 609-629.

Gerged, A. M., \& Almontaser, T., 2021. Corporate adoption of SDG reporting in a non-enabling institutional environment: Insights from Libyan oil industries. Resources Policy, 74, 102240.

Gerged, A. M., Albitar, K., \& Al-Haddad, L., 2021a. Corporate environmental disclosure and earnings management-The moderating role of corporate governance structures. International Journal of Finance \& Economics, Forthcoming.

Gerged, A. M., Beddewela, E. S., \& Cowton, C. J., 2021b. Does the quality of country-level governance have an impact on corporate environmental disclosure? Evidence from Gulf Cooperation Council countries. International Journal of Finance \& Economics, Forthcoming.

Gerged, A. M., Beddewela, E., \& Cowton, C. J., 2021c. Is corporate environmental disclosure associated with firm value? A multicountry study of Gulf Cooperation Council firms. Business Strategy and the Environment, 30(1), 185-203.

Gerged, A., \& Elheddad, M., 2020. How can national governance affect education quality in Western Europe?. International Journal of Sustainability in Higher Education, 21(3), 413426.

Gerged, A., and Agwili, A., 2019. How Corporate Governance affect Firm Value and profitability? Evidence from Saudi Financial and Non-Financial Listed Firms. International Journal of Business Governance and Ethics, 14(1), 144 - 164.

Ghafran, C. and O'Sullivan, N., 2013. The governance role of audit committees: Reviewing a decade of evidence. International Journal of Management Reviews, 15, 381-407

Ghafran, C. and O'Sullivan, N., 2017. The impact of audit committee expertise on audit quality: Evidence from UK audit fees. The British Accounting Review, 49(6), 578-593.

Glaum, M., Lichtblau, K., \& Lindemann, J., 2004. The extent of earnings management in the US and Germany. Journal of International Accounting Research, 3(2), 45-77.

Greene, R., 2017. Human behaviour theory: A diversity framework. Routledge.

Healy, P. M., \& Palepu, K. G., 2001. Information asymmetry, corporate disclosure, and the capital markets: A review of the empirical disclosure literature. Journal of Accounting and Economics, 31(1-3), 405-440.

Ho, L. J., Liu, C., \& Wang, X. F. 2014. To what extent does the audit committee curb downward earnings forecast guidance? Review of Accounting and Finance, 13(2), 110-133.

Hogan, C.E., Schmidt, J.J. and Thompson, A.M., 2014. Audit Committee Responsibilities and Implications for Legal Liability. [online], 1-38. Available at: http://www.isarhq.org/2014 downloads/papers/ISAR2014 Hogan Schmidt Thompson. pdf [Accessed 05th October 2017]

Hussey, J., \& Hussey, R., 1997. Business research: A practical guide for undergraduate and postgraduate students. Basingstoke, UK: Palgrave MacMillan.

Ivankova, N. V., Creswell, J. W., \& Stick, S. L. (2006). Using mixed-methods sequential explanatory design: From theory to practice. Field methods, 18(1), 3-20.

Jackson, G. and Apostolakou, A., 2010. Corporate social responsibility in Western Europe: an institutional mirror or substitute? Journal of Business Ethics, 94, 371-394

Jensen, M. C., \& Meckling, W. H., 1976. Theory of the firm: Managerial behaviour, agency costs and ownership structure. Journal of Financial Economics, 3(4), 305-360.

Jizi, M.I., Salama, A., Dixon, R. and Stratling, R., 2014. Corporate governance and corporate social responsibility disclosure: Evidence from the US banking sector, Journal of Business Ethics, $125,601-615$

Jun Lin, Z., Xiao, J.Z. and Tang, Q. 2008. The roles, responsibilities and characteristics of the audit committee in China. Accounting, Auditing \& Accountability Journal, 21(5), 721-751 
Kalbers, L. P., \& Fogarty, T. J., 1998. Organizational and economic explanations of audit committee oversight. Journal of Managerial Issues, 10(2), (Summer 1998), 129-150.

Keune, M. B., \& Johnstone, K. M., 2012. Materiality judgments and the resolution of detected misstatements: The role of managers, auditors, and audit committees. The Accounting Review, 87(5), 1641-1677.

Kim, H. T., \& Suk, I. H., 2012. Does equity-based compensation of audit committee and CEO increase earnings management? New evidence, 2012(2), 100-150.

Klapper, L. F., \& Love, I., 2004. Corporate governance, investor protection, and performance in emerging markets. Journal of Corporate Finance, 10(5), 703-728.

Klein, A., 2002. Audit committee, the board of director characteristics, and earnings management. Journal of Accounting and Economics, 33(3), 375-400.

Krishnan, J., 2005. Audit committee quality and internal control: An empirical analysis. The Accounting Review, 80(2), 649-675.

Kumati, A., 2008. Commercial banking in Libya and the potential for Islamic banking (Doctoral dissertation, Durham University).

La Porta, R., F. Lopez-de-Silanes., A. Shleifer, and R. Vishny., 1998. Law and Finance, Journal of Political Economy, 106(6), 1113-1155.

Larbsh, M.M., 2010. An Evaluation of Corporate Governance Practice in Libya: Stakeholders' Perspectives. PhD thesis., Nottingham Trent University.

Leuz, C., Nanda, D., \& Wysocki, P. D., 2003. Earnings management and investor protection: An international comparison. Journal of Financial Economics, 69(3), 505-527.

Levitt, A., 2000. Renewing the covenant with investors. Speech by Chairman Arthur Levitt, U.S. Securities and Exchange Commission, at New York University's Center for Law and Business. New York, NY: SEC.

Lin, J. W., Li, J. F., \& Yang, J. S., 2006. The effect of audit committee performance on earnings quality. Managerial Auditing Journal, 21(9), 921-933.

Lin, J., Z, Xiao, J. Z., \& Tang, Q., 2008. The roles, responsibilities and characteristics of the audit committee in China. Accounting, Auditing \& Accountability Journal, 21(5), 721-751.

Maatoug, A. G. S., 2014. Accounting Education in Libya: An Institutional Perspective. PhD thesis, University of Dundee.

Macey, J. R., \& O'Hara, M., 2003. The corporate governance of banks. Economic Policy Review, 9(Apr), 91-107.

Mangena, M., \& Chamisa, E., 2008. Corporate governance and incidences of listing suspension by the JSE securities exchange of South Africa: An empirical analysis. The International Journal of Accounting, 43(1), 28-44.

Mangena, M., \& Pike, R., 2005. The effect of audit committee shareholding, financial expertise and size on interim financial disclosures. Accounting and Business Research, 35(4), 327-349.

Mangena, M., \& Tauringana, V., 2008. Audit committees and voluntary external auditor involvement in UK interim reporting. International Journal of Auditing, 12(1), 45-63.

Mangena, M., Tauringana, V., \& Chamisa, E., 2012. Corporate boards, ownership structure and firm performance in an environment of severe political and economic crisis. British Journal of Management, 23, S23-S41.

Maraghni, I., \& Nekhili, M., 2014. Audit committee diligence in French companies: A question of independence or competence? Comptabilité-Contrôle-Audit, 20(2), 95-124.

Masli, A.M., 2018. The Role of the Audit Committee as a Corporate Governance Mechanism: The Case of the Banking Sector in Libya. PhD thesis., Nottingham Trent University.

Masli, A.M., Mangena, M. and Harradine, D., 2019. The Role of Audit Committees in the Libyan Banking Sector as it Transforms into an Islamic System. International Journal of Islamic Economics and Finance Studies, 5(2), 1-22.

Masoud, N., 2014a. What the Libyan Economy Can Learn from Emerging Countries. In: The 2010 University of Huddersfield Annual Learning and Teaching Conference, University of Huddersfield, Huddersfield, UK: Available at SSRN: https://ssrn.com/abstract $=2429827$

Matten, D. and Moon, J. (2008). 'Implicit' and 'explicit' CSR: a conceptual framework for a comparative understanding of corporate social responsibility. Academy of Management Review 33, 404- 424. 
McDaniel, L., Martin, R. D., \& Maines, L. A., 2002. Evaluating financial reporting quality: The effects of financial expertise vs financial literacy. The Accounting Review, 77(s-1), 139-167.

Meyer, J. W., \& Rowan, B., 1977. Institutionalized organizations: Formal structure as myth and ceremony. American Journal of Sociology, 83(2), 340-363.

Nganga, S., Jain, V. and Artivor, M., 2003. Corporate Governance in Africa: A Survey of Publicly Listed Companies. London Business School, United Kingdom. Available at: http://www.africaplc.com/typetool/uploads/main news/docs/CGiA\%20Final\%20Report.p df.

Nuskiya, M. N. F., Ekanayake, A., Beddewela, E., \& Gerged, A., 2021. Determinants of corporate environmental disclosures in Sri Lanka: the role of corporate governance. Journal of Accounting in Emerging Economies, 11(3), 367-394.

Okeahalam, C. C., 2004. Corporate governance and disclosure in Africa: Issues and challenges. Journal of Financial Regulation and Compliance, 12(4), 359-370.

Okpara, J. O., 2011. Corporate governance in a developing economy: Barriers, issues, and implications for firms. Corporate Governance: The International Journal of Business in Society, 11(2), 184-199.

Poretti, C., Schatt, A. and Bruynseels, L., 2018. Audit committees' independence and the information content of earnings announcements in Western Europe. Journal of Accounting Literature, 40, 29-53.

Pucheta-Martínez, M. C., \& García-Meca, E., 2014. Institutional investors on boards and audit committees and their effects on financial reporting quality. Corporate Governance: An International Review, 22(4), 347-363.

Qasim, A., 2018. Audit committee effectiveness: reflections from the UAE. International Journal of Economics and Business Research, 15(1), 87-107.

Rae, K., Sands, J., \& Subramaniam, N., 2017. Associations among the five components within COSO internal control integrated framework as the underpinning of quality corporate governance. Australasian Accounting, Business and Finance Journal, 11(1), 28-54.

Raghunandan, K., \& Rama, D. V., 2007. Determinants of audit committee diligence. Accounting Horizons, 21(3), 265-279.

Rainsbury, E. A., Bradbury, M. E., \& Cahan, S. F., 2008. Firm characteristics and audit committees are complying with best practice 'membership guidelines. Accounting and Business Research, 38(5), 393-408.

Reddy, K., Abidin, S., \& You, L., 2015. Does corporate governance matter in determining CEO compensation in the publicly listed companies in New Zealand? An empirical investigation. Managerial Finance, 41(3), 301-327.

Rezaee, Z., 2009. Corporate Governance and Ethics. New York, USA: John Wiley \& Sons, Inc.

Saad, M., et al., 2006. Audit committee authority and effectiveness: The perceptions of Malaysian senior managers. [online], Available at: SSRN: https://ssrn.com/abstract=924130 [Accessed 15th March 2018].

Sanjaya, I. P. S., 2016. The influence of audit committee on earnings management. Jurnal Akuntansi Dan Investasi., 7(1), 97-112.

Sarbanes Oxley Act, 2002. One Hundred Seventh Congress of the USA. An Act, US Sarbanes Oxley Act, 2002. [online], Available at: https://www.gpo.gov/fdsys/pkg/BILLS107hr3763enr/pdf/BILLS-107hr3763enr.pdf [Accessed 18th March 2018].

Scott, W. R., 1987. The adolescence of institutional theory. Administrative Science Quarterly, 493511.

Shalba, A., 2016. An investigation of the roles and responsibilities of the board of directors in the Libyan banking sector. PhD, thesis., Nottingham Trent University).

Sharma, V., Naiker, V., \& Lee, B., 2009. Determinants of audit committee meeting frequency: Evidence from a voluntary governance system. Accounting Horizons, 23(3), 245-263.

Shernanna, H., 2012. Critical Perspectives on the Efficient Implementation of Privatisation Policies in Libya: Assessing Financial, Economic, Legal, Administrative and Social Requirements. PhD thesis., Durham University.

Smith, R., 2003. Audit committees combined code guidance: A report and proposed guidance by an FRC-appointed group. London: Financial Reporting Council (FRC). 
Sonpar, K., Pazzaglia, F., \& Kornijenko, J., 2010. The paradox and constraints of legitimacy. Journal of Business Ethics, 95(1), 1-21.

Spira, L.F. and Bender, R., 2004. Compare and contrast: Perspectives on board committees. Corporate Governance: An International Review, 12(4), 489-499.

Stewart, B., 2006. The real reasons Enron failed. Journal of Applied Corporate Finance, 18 (2), 116-119.

Suchan, S.W., 2004. Post-Enron: US and German Corporate Governance. Cornell Law School Graduate Student Papers [online], 6-7-2004, 1-46. Available at: https://scholarship.law.cornell.edu/lps_papers/4/ [Accessed 15th March 2018].

Suchman, M. C., 1995. Managing legitimacy: Strategic and institutional approaches. Academy of Management Review, 20(3), 571-610.

Sun, J. and Liu, G., 2014. Audit committees' oversight of bank risk-taking, Journal of Banking \& Finance, 40, 376-387

The Libyan Stock Market., 2007. Rules and Regulations of Libyan Stock Market: Libyan Code Corporate Governance.

Thiruvadi, S., 2012. Gender differences and audit committee diligence. Gender in Management: An International Journal, 27(6), 366-379.

Turley, S., \& Zaman, M., 2014. The corporate governance effects of the audit committee. Accounting and Regulation. Berlin, Germany: Springer, 2014, pp. 133-159.

Waweru, N., Mangena, M. and Riro, G., 2019. Corporate governance and internet reporting by listed firms in Kenya and Tanzania. Corporate Governance: The International Journal of Business in Society, 19(4), 751-773

Wu, H., \& Patel, C., 2015. Adoption of Anglo-American models of corporate governance and financial reporting in China. London: Emerald Group Publishing.

Zagoub, A. A., 2011. Corporate governance in Libyan commercial banks (Doctoral dissertation, University of Dundee).

Zagoub, A. A., 2017. Structure and responsibilities of corporate boards in Libyan commercial banks: Insights from institutional theory. Journal of Dirasat in Economics and Business Studies, 33-34.

Zahoor, N., \& Gerged, A. M., 2021. Relational capital, environmental knowledge integration and environmental performance of SMEs in emerging markets. Business Strategy and the Environment, Forthcoming. 


\begin{tabular}{|c|c|c|c|c|c|c|}
\hline & Questionnaires Distributed & Questionnaires Analysed & Analysed \% & Overall \% & Interviewees & Overall \% \\
\hline \multicolumn{7}{|c|}{ Panel A: Groups of respondents } \\
\hline Board Members & 64 & 21 & $32.8 \%$ & $9.6 \%$ & 4 & $20 \%$ \\
\hline AC Members & 48 & 17 & $35.4 \%$ & $7.8 \%$ & 4 & $20 \%$ \\
\hline $\begin{array}{l}\text { Executive } \\
\text { Managers }\end{array}$ & 112 & 74 & $66.1 \%$ & $33.9 \%$ & 4 & $20 \%$ \\
\hline Internal Auditors & 112 & 71 & $63.4 \%$ & $32.6 \%$ & 4 & $20 \%$ \\
\hline External Auditors & 64 & 35 & $54.7 \%$ & $16.1 \%$ & 4 & $20 \%$ \\
\hline Total & 400 & 218 & $54.5 \%$ & $100 \%$ & 20 & $100 \%$ \\
\hline \multicolumn{7}{|c|}{ Panel B: Profile of respondents on the questionnaire } \\
\hline & Board Members & AC Members & Executive Managers & Internal Auditors & External Auditors & All Five Groups \\
\hline Education & $\mathrm{No}(\%)$ & $\mathrm{No}(\%)$ & $\mathrm{No}(\%)$ & $\mathrm{No}(\%)$ & $\mathrm{No}(\%)$ & $\mathrm{No}(\%)$ \\
\hline $\mathrm{PhD}$ & $7(33.3 \%)$ & $3(17.6 \%)$ & $5(6.8 \%)$ & 0 & $3(8.6 \%)$ & $18(8.3 \%)$ \\
\hline Masters & $7(33.3 \%)$ & $8(47.1 \%)$ & $28(37.8 \%)$ & $16(22.5 \%)$ & $11(31.4 \%)$ & $70(32.1 \%)$ \\
\hline First Degree (BA) & $7(33.3 \%)$ & $6(35.3 \%)$ & $36(48.6 \%)$ & $41(57.7 \%)$ & $21(60 \%)$ & $111(50.9 \%)$ \\
\hline Other & 0 & 0 & $5(6.8 \%)$ & $14(19.7 \%)$ & 0 & $19(8.7 \%)$ \\
\hline Total & $21(100 \%)$ & $17(100 \%)$ & $74(100 \%)$ & $71(100 \%)$ & $35(100 \%)$ & $218(100 \%)$ \\
\hline Major & No(\%) & No(\%) & $\mathrm{No}(\%)$ & $\mathrm{No}(\%)$ & No(\%) & No(\%) \\
\hline Accounting & $10(47.6 \%)$ & $10(58.5 \%)$ & $41(55.4 \%)$ & $48(67.6 \%)$ & $33(94.3 \%)$ & $142(65.1 \%)$ \\
\hline Finance & $3(14.3 \%)$ & $3(17.6 \%)$ & $4(5.4 \%)$ & $4(5.6 \%)$ & $2(5.7 \%)$ & $16(7.3 \%)$ \\
\hline Economics & $2(9.5 \%)$ & $1(5.9 \%)$ & $4(5.3)$ & $5(7.1 \%)$ & 0 & $12(5.5 \%)$ \\
\hline Management & $4(19 \%)$ & $2(11.8 \%)$ & $19(25.7 \%)$ & $11(15.5 \%)$ & 0 & $63(16.5 \%)$ \\
\hline Other & $2(9.5 \%)$ & $1(5.9 \%)$ & $6(8.1 \%)$ & $3(4.2 \%)$ & 0 & $12(5.5 \%)$ \\
\hline Total & $21(100 \%)$ & $17(100 \%)$ & $74(100 \%)$ & $71(100 \%)$ & $35(100 \%)$ & $218(100 \%)$ \\
\hline Experience & $\mathrm{No}(\%)$ & $\mathrm{No}(\%)$ & No(\%) & No(\%) & $\mathrm{No}(\%)$ & No $(\%)$ \\
\hline Less than 5 years & 0 & 0 & $3(4.1 \%)$ & $7(9.9 \%)$ & $2(5.8 \%)$ & $12(5.5 \%)$ \\
\hline From 5 to 10 years & $3(14.3 \%)$ & $6(35.3 \%)$ & $12(16.2 \%)$ & $11(15.5 \%)$ & $6(17.1 \%)$ & $38(17.4 \%)$ \\
\hline From 10 to 15 years & $5(23.8 \%)$ & $4(23.5 \%)$ & $12(16 \%)$ & $14(20 \%)$ & $6(17.1 \%)$ & $40(18.8 \%)$ \\
\hline More than 15 years & $13(61.9 \%)$ & $7(41.2 \%)$ & $47(63.5 \%)$ & $39(54.9 \%)$ & $21(60 \%)$ & $127(58.3 \%)$ \\
\hline Total & $21(100 \%)$ & $17(100 \%)$ & $74(100 \%)$ & $71(100 \%)$ & $35(100 \%)$ & $218(100 \%)$ \\
\hline \multicolumn{7}{|c|}{ Panel C: Profile of the Interviewees } \\
\hline & Board Members & AC Members & Executive Managers & Internal Auditors & External Auditors & All Five Groups \\
\hline Education & $\mathrm{No}(\%)$ & No(\%) & $\mathrm{No}(\%)$ & $\mathrm{No}(\%)$ & $\mathrm{No}(\%)$ & No(\%) \\
\hline $\mathrm{PhD}$ & $2(50 \%)$ & $2(50 \%)$ & 0 & 0 & $1(25 \%)$ & $5(25 \%)$ \\
\hline Masters & $1(25 \%)$ & 0 & $4(100 \%)$ & $2(50 \%)$ & $3(75 \%)$ & $10(50 \%)$ \\
\hline First Degree (BA) & $1(25 \%)$ & $2(50 \%)$ & 0 & $2(50 \%)$ & 0 & $5(25 \%)$ \\
\hline Other & 0 & 0 & 0 & 0 & 0 & 0 \\
\hline Total & $4(100 \%)$ & $4(100 \%)$ & $4(100 \%)$ & $4(100 \%)$ & $4(100 \%)$ & $20(100 \%)$ \\
\hline Major & $\mathrm{No}(\%)$ & $\mathrm{No}(\%)$ & $\mathrm{No}(\%)$ & No(\%) & No(\%) & $\mathrm{No}(\%)$ \\
\hline Accounting & $3(75 \%)$ & $4(100 \%)$ & $1(25 \%)$ & $3(75 \%)$ & $3(75 \%)$ & $14(70 \%)$ \\
\hline Finance & $1(25 \%)$ & 0 & $1(25 \%)$ & $1(25 \%)$ & 0 & $3(15 \%)$ \\
\hline Economics & 0 & 0 & $1(25 \%)$ & 0 & 0 & $1(5 \%)$ \\
\hline Management & 0 & 0 & $1(25 \%)$ & 0 & $1(25 \%)$ & $2(10 \%)$ \\
\hline Other & 0 & 0 & 0 & 0 & 0 & 0 \\
\hline Total & $4(100 \%)$ & $4(100 \%)$ & $4(100 \%)$ & $4(100 \%)$ & $4(100 \%)$ & 20 \\
\hline Experience & No(\%) & No(\%) & $\mathrm{No}(\%)$ & $\mathrm{No}(\%)$ & No(\%) & $\mathrm{No}(\%)$ \\
\hline Less than 5 years & 0 & 0 & 0 & 0 & 0 & 0 \\
\hline From 5 to 10 years & 0 & 0 & 0 & $2(50 \%)$ & 0 & $2(10 \%)$ \\
\hline From 10 to 15 years & 0 & 0 & 0 & 0 & $1(25 \%)$ & $1(5 \%)$ \\
\hline More than 15 years & $4(100 \%)$ & $4(100 \%)$ & $4(100 \%)$ & $2(50 \%)$ & $3(75 \%)$ & $17(85 \%)$ \\
\hline Total & $4(100 \%)$ & $4(100 \%)$ & $4(100 \%)$ & $4(100 \%)$ & $4(100 \%)$ & $20(100 \%)$ \\
\hline
\end{tabular}




Panel A: Audit Committee Effectiveness (ACE)

Review of financial statements (RFS)

of the survey. It is measured by four statements are;

1- The AC reviews significant accounting policies, any changes to them and any significant estimates.

2- The AC monitors the extent to which the process of the financial statements complies with accounting standards.

3- The AC reviews and monitors external audit reports concerning financial statements.

4- The AC reviews and monitors corrections made by management concerning financial statements reported by internal auditors.

In an effort to enhance its effectiveness, an AC relies on the internal audit department to gain access to information on financial and operating Khelil et al., 2016; matters within the organisation. Often called the "eyes and ears" of the AC, the internal audit is able to assist the committee in a number of Eller, 2014 ways, such as recommending external auditors, negotiating their fees and then evaluating their work. This may include working with internal and external auditors to remediate any material weaknesses in the internal control systems. ACs' engagement with internal auditors is measured in this study by eight statements in the questionnaire, which are;

Engagement with internal $\quad 1$ - The AC reviews the objectives, plan, functions and terms of reference of the internal audit.

auditors (EIA)

1- The $A C$ reviews the objectives, plan, functions and terms of reference of th
2- The $A C$ reviews the internal audit reports and any actions taken as a result.

3- The AC ensures that the internal audit has the necessary resources and access to information.

4- The AC receives reports on the results of the work of internal auditors.

5- The AC meets with the chief of internal audit at least once a year without the presence of management.

6- The AC promotes the independence of the internal auditors

7- The AC can recommend the appointment or replacement of an internal auditing director.

8- The AC reviews and examines the effectiveness of internal controls and their evaluation by auditors.

Effective ACs play a significant role in promoting the independence and objectivity of the external audit process. This aspect of ACE was, Bédard and

therefore, the focus of the third section of the survey. It is measured by five statements that are

Engagement with

1- The AC reviews and monitors the activities, resources, expertise and independence of the external auditors.

external auditors (EEA)

2- The AC reviews and investigates the findings of the annual audit provided by the external auditors.

3- The AC reviews that the audit fees are adequate to perform the audit process effectively

4- The AC meets with the external auditors without the presence of the management to discuss issues related to the audit process.

5- External auditors are appointed and replaced at the recommendation of the AC.

Overall AC effectiveness This variable is measured by computing the average score of participants' responses to ACs' role in reviewing financial statements (4 statements), ACs' engagement with internal auditors (8 statements) and external auditors (5 statements).

AC authority

Panel B: Firm-level Determinants of ACE

AC authority is central to its ability to monitor the financial reporting process, and therefore, it is a key determinant of its effectiveness. AC authority is highly dependent on the strength of its relationships with external and internal auditors, managers and the board as a whole. In this study, AC authority includes AC influence, AC's access information, board governance and legal requirements governing the AC's responsibilities in the Libyan banking sector (LBS). It is measured in the questionnaire by asking the following question:

- Do you think that the AC has sufficient authority and influence to carry out its responsibilities? Please explain your view.

- Can the AC easily access the required information in the bank?

- In your opinion, is the lack of clear legal requirements governing the AC's responsibilities or duties inhibiting ACE in the Libyan banks?

- In your opinion, is the weaknesses in board governance inhibiting ACE in the Libyan banks? 
- In your view, do the AC members have adequate experience in accounting practices? Do AC members have adequate knowledge about the firm's business?

$\mathrm{AC}$ independence $\quad \mathrm{AC}$ independence is seen as vital if the committee is to be able to perform its duty; therefore, most researchers and institutions recommend that the AC should be made up of non-executive and independent directors. AC independence implies that AC members should not be receiving any consultancy, advisory or other fees from the company or be affiliated with it in any way. In other words, NEDs should have no business or other relationship with the company, which could materially interfere with the exercise of their independent judgement. We define AC independence as ACs' non-executive members, qualifications and experience of AC members and compensation paid to AC members in the LBS. It is measured in the questionnaire by asking the following question:

- How are AC members chosen and appointed?

- How do you evaluate the independence of the AC in your bank?

- In your view, is the inadequate compensation paid to AC members inhibiting ACE in the Libyan banks?

$\mathrm{AC}$ resources $\quad \mathrm{AC}$ resources (size) means that ACs should have sufficient members to perform the functions and duties assigned to them. It is the number AC resources (size) means that ACs should have sufficient members to perform the functions and duties
of $A$ memers in the LBS, which is measured in the questionnaire by asking the following question:

Do you think that the AC in the bank has enough members to perform its duties and responsibilities adequately?

AC diligence $\quad A C$ diligence is defined as being careful and thorough in one's work or efforts. The diligence of $A C$ members is crucial in ensuring that the committee performs its responsibilities effectively and with integrity. AC diligence in our study represents AC time and effort and AC meeting in the LBS, which is measured in the questionnaire by asking the following question:

- In your view, does the AC meet often enough to perform its duties and responsibilities properly and to discuss all relevant issues? - Do AC members devote adequate time and effort to perform their duties and responsibilities? Please explain how?

\section{Panel C: National-level Determinants of ACE}

Legal and regulatory The OECD (2004) recognises the significance of the prevailing legal, regulatory and institutional environment in shaping and supporting the

environment $\quad$ CG framework. In the case of Libya, an outdated legal system and inconsistent enforcement do little to inspire confidence in investors and is adversely affecting CG in Libya by failing to define the board's responsibilities in law. This study focuses on the legal and regulatory environment of the LBS, which measured in the questionnaire by asking the following question:

In your opinion, is the weak legal and regulatory environment inhibiting ACE in the Libyan banks?

The Libyan Government has been half-hearted in its attempts to reform governance because, as the largest shareholder, it has the most to gain from the status quo - it controls the economy at the expense of other shareholders. Political intervention affects CG in Libya, for

Government

intervention example, through the Central Bank of Libya's involvement in the appointment of board members. This has a knock-on effect on the selection of $A C$ and other committee members and, in turn, the decision making and performance of these entities. This study focuses on government intervention in the LBS, which measured in the questionnaire by asking the following question:

In your opinion, is Government intervention in the banking sector, especially from the Central Bank, inhibiting ACE?

Accounting The accounting and auditing professions in Libya do not enjoy high status, mostly due to the perceived weakness of the Libyan Accountants

environment and Auditors Association. This study focuses on the accounting environment of the LBS, which measured in the questionnaire by asking the following question: 
Table 3: Descriptive Statistics

\begin{tabular}{|c|c|c|c|c|c|c|c|c|c|}
\hline \multirow{2}{*}{ Statements } & \multicolumn{5}{|c|}{ Group Means } & \multirow{2}{*}{$\begin{array}{c}\text { Total } \\
\text { Mean Score }\end{array}$} & \multirow{2}{*}{ Median } & \multirow{2}{*}{$\begin{array}{l}\text { Standard } \\
\text { Deviation }\end{array}$} & \multirow{2}{*}{$\begin{array}{l}\text { Kruskal- } \\
\text { Wallis } \\
\text { Chi-Sq }\end{array}$} \\
\hline & BD & AC & EM & IA & EA & & & & \\
\hline \multicolumn{10}{|c|}{ Panel A: Perceptions of ACE } \\
\hline Overall AC effectivness & 3.80 & 3.72 & 3.49 & 3.65 & 3.71 & 3.68 & 4.00 & 1.04 & 4.30 \\
\hline Monitoring Financial Statements & 3.85 & 3.60 & 3.60 & 3.70 & 3.75 & 3.68 & 4.00 & 1.06 & $1.59^{* *}$ \\
\hline Monitoring Internal Auditing & 3.85 & 3.89 & 3.61 & 3.83 & 3.72 & 3.75 & 4.00 & 1.00 & 3.37 \\
\hline Monitoring External Auditing & 3.69 & 3.55 & 3.20 & 3.32 & 3.36 & 3.34 & 3.00 & 1.05 & 9.65 \\
\hline \multicolumn{10}{|c|}{ Panel B: Firm-level Determinants of ACE } \\
\hline AC authority & 3.39 & 3.84 & 3.45 & 3.48 & 3.86 & 3.56 & 4.00 & 1.06 & 2.54 \\
\hline AC financial expertise & 4.57 & 4.47 & 3.97 & 3.93 & 4.20 & 4.09 & 4.00 & 0.94 & $15.80^{* * *}$ \\
\hline AC independence & 3.27 & 3.61 & 3.27 & 3.31 & 3.66 & 3.37 & 3.00 & 1.09 & $9.50^{* *}$ \\
\hline$A C$ resources & 3.62 & 3.76 & 3.65 & 3.56 & 3.73 & 3.64 & 4.00 & 0.95 & 0.81 \\
\hline AC diligence & 3.65 & 3.74 & 3.41 & 3.52 & 3.65 & 3.52 & 4.00 & 0.97 & 2.96 \\
\hline \multicolumn{10}{|c|}{ Panel C: National-level Determinants of ACE } \\
\hline $\begin{array}{l}\text { Legal and regulatory } \\
\text { environment }\end{array}$ & 4.00 & 4.12 & 3.95 & 3.66 & 4.26 & 3.92 & 4.00 & 1.07 & $13.58^{* * *}$ \\
\hline Government intervention & 3.57 & 3.59 & 3.77 & 3.70 & 3.66 & 3.70 & 4.00 & 1.02 & 1.49 \\
\hline Accounting environment & 3.67 & 3.65 & 3.19 & 3.45 & 3.51 & 3.41 & 4.00 & 1.29 & 2.57 \\
\hline
\end{tabular}

Note: BD is Board members, AC is Audit committee members, EM is Executive managers, IA is Internal auditors, and EA is External auditors. ${ }^{* * *}$ and ${ }^{* *}$ denote $p$-value is respectively significant at the levels $1 \%$ and $5 \%$. 
Table 4: Pearson correlation analysis

\begin{tabular}{|c|c|c|c|c|c|c|c|c|}
\hline & Authority & Financial expertise & Independent & Recourses & Diligence & $\begin{array}{c}\text { Legal } \\
\text { environment } \\
\end{array}$ & $\begin{array}{l}\text { Government } \\
\text { intervention }\end{array}$ & $\begin{array}{l}\text { Accounting } \\
\text { environmen }\end{array}$ \\
\hline \multicolumn{9}{|l|}{ Authority } \\
\hline Financial expertise & 0.095 & & & & & & & \\
\hline Independent & $-0.221^{* *}$ & 0.059 & & & & & & \\
\hline Resources & 0.122 & $0.332^{* *}$ & $0.205^{* *}$ & & & & & \\
\hline Diligence & $0.403^{* *}$ & $0.411^{* *}$ & -0.059 & $0.490^{* *}$ & & & & \\
\hline Government intervention & 0.106 & $-0.186^{\star *}$ & $-0.258^{* *}$ & $-0.137^{*}$ & -0.117 & $0.436^{* *}$ & & \\
\hline $\begin{array}{l}\text { Accounting environment } \\
\text { ACE }\end{array}$ & $\begin{array}{l}-0.018 \\
0.203^{\text {** }}\end{array}$ & $\begin{array}{l}-0.179^{* *} \\
0.427^{\star *}\end{array}$ & $\begin{array}{c}-0.177^{\star *} \\
0.113\end{array}$ & $\begin{array}{l}-0.028 \\
0.311^{* *}\end{array}$ & $\begin{array}{l}-0.238^{* *} \\
0.518^{* *}\end{array}$ & $\begin{array}{l}0.462^{* *} \\
-0.151^{*}\end{array}$ & $\begin{array}{l}0.504^{* *} \\
-0.215^{* *}\end{array}$ & $-0.158^{*}$ \\
\hline
\end{tabular}


Table 5: Regression analysis of the determinants of ACs' effectiveness

\begin{tabular}{|c|c|c|c|c|}
\hline $\begin{array}{c}\text { Models } \\
\text { Variables }\end{array}$ & $\begin{array}{c}\text { (1) } \\
\text { Overall ACE } \\
\text { B Coefficient (t) }\end{array}$ & $\begin{array}{c}(2) \\
\text { RFS } \\
\text { B Coefficient (t) }\end{array}$ & $\begin{array}{c}(3) \\
\text { EIA } \\
\text { B Coefficient (t) }\end{array}$ & $\begin{array}{c}(4) \\
\text { EEA } \\
\text { B Coefficient (t) } \\
\end{array}$ \\
\hline \multicolumn{5}{|c|}{ Panel A: Firm-level Determinants of ACE } \\
\hline Authority & $0.573(2.144)^{* *}$ & $0.097(1.039)$ & $0.341(2.244)^{* *}$ & $0.135(1.180)$ \\
\hline Financial expertise & $2.219(3.290) * * *$ & $0.467(1.981)^{* *}$ & $1.185(3.087)^{* * *}$ & $0.568(1.971)^{* *}$ \\
\hline Independent & $0.383(1.434)$ & $0.059(0.630)$ & $0.154(1.015)$ & $0.170(1.490)$ \\
\hline Recourses & $0.087(0.126)$ & $0.139(0.579)$ & $0.107(0.274)$ & $-0.159(-0.543)$ \\
\hline Diligence & $3.197(7.494) * * *$ & $0.838(5.626) * * *$ & $1.479(6.090) * * *$ & $(4.831) 0.880^{\star * *}$ \\
\hline \multicolumn{5}{|c|}{ Panel B: Country-level Determinants of ACE } \\
\hline Legal and regulatory environment & $-1.953(3.067)^{* * *}$ & $-0.566(2.543) * *$ & $-1.066(2.941) * * *$ & $-0.321(1.182)$ \\
\hline Government intervention & $-1.008(1.601)$ & $-0.686(3.120) * * *$ & $-0.440(1.227)$ & $0.118(0.438)$ \\
\hline $\begin{array}{l}\text { Accounting and auditing } \\
\text { environment }\end{array}$ & $-1.340(2.688)^{* * *}$ & $0.773(4.438) * * *$ & $-0.725(2.556) * *$ & $-0.158(0.742)$ \\
\hline \multicolumn{5}{|c|}{ Panel C: Control Variables } \\
\hline Stakeholder group 1 & $4.552(1.014)$ & $0.082(0.052)$ & $1.937(0.759)$ & $2.533(1.321)$ \\
\hline Stakeholder group 2 & $1.364(0.567)$ & $0.808(0.961)$ & $1.500(1.095)$ & $-0.945(-0.918)$ \\
\hline Stakeholder group 3 & $2.897(0.621)$ & $-0.201(-0.124)$ & $1.542(0.581)$ & $1.556(0.781)$ \\
\hline Type of qualification & $-3.790(0.530)$ & $0.418(0.167)$ & $-2.910(-.715)$ & $-1.298(-0.425)$ \\
\hline Experience & $-8.689(1.555)$ & $0.054(0.028)$ & $-5.681(-1.786) *$ & $-3.062(-1.283)$ \\
\hline Constant & $24.824(2.656)$ *** & $4.457(1.365)$ & $12.003(2.262)^{* *}$ & $8.333(2.087)^{* *}$ \\
\hline Adjusted $\mathrm{R}^{2}$ & 0.480 & 0.346 & 0.400 & 0.260 \\
\hline F-value & 16.388 & 9.814 & 12.142 & 6.861 \\
\hline
\end{tabular}

Note: ACE is the audit committees' effectiveness as measured by three main components are ACs' role in (i) reviewing the financial statements (RFS), (ii) engagement with internal auditors (EIA), and finally (iii) engagement with external auditors (EEA). Stakeholder group 1 is measured as 1 if the participant was a board member (including AC members) and 0 otherwise. Stakeholder group 2 is measured as 1 if the participant was an executive manager and 0 otherwise. Stakeholder group 3 is measured as 1 if the participant was an auditor (internal or external) and 0 otherwise. Type of qualification is measured as 1 if the participant holds a qualification in accounting, finance and economics and 0 otherwise. Experience is measured as 1 if the participant has a professional experience exceeding 5 years and 0 otherwise. Coefficients are in front of the parenthesis. ${ }^{* * *},{ }^{* *}$ and ${ }^{*}$ denote $\mathrm{p}$-value is respectively significant at the levels $1 \%, 5 \%$ \& $10 \%$. 
Table 6: Additional Regression Analysis using more detailed determinants (14) than the main analysis (eight)

\begin{tabular}{|c|c|c|c|c|}
\hline $\begin{array}{c}\text { Models } \\
\text { Variables }\end{array}$ & $\begin{array}{c}(1) \\
\text { Overall ACE } \\
\text { B Coefficient (t) }\end{array}$ & $\begin{array}{c}(2) \\
\text { RFS } \\
\text { B Coefficient (t) }\end{array}$ & $\begin{array}{c}(3) \\
\text { EIA } \\
\text { B Coefficient }(t)\end{array}$ & $\begin{array}{c}(4) \\
\text { EEA } \\
\text { B Coefficient } \\
(\mathrm{t}) \\
\end{array}$ \\
\hline \multicolumn{5}{|c|}{ Panel A: Firm-level Determinants of ACE } \\
\hline \multicolumn{5}{|l|}{ AC Authority } \\
\hline Influence of $A C$ & $1.871(2.721)^{* * *}$ & $0.603(2.560) * *$ & $0.586(1.495)$ & $0.68(2.337) * *$ \\
\hline AC's access to information & $0.051(0.080)$ & $-0.268(-1.231)$ & $0.166(0.456)$ & $0.153(0.569)$ \\
\hline Board governance & $0.014(0.022)$ & $-0.035(-0.163)$ & $0.080(0.226)$ & $-0.032(-0.121)$ \\
\hline Legal requirements supporting ACs & $0.452(0.693)$ & $0.220(0.987)$ & $0.512(1.376)$ & $-0.280(-1.013)$ \\
\hline Financial expertise of $A C$ & $1.822(2.617)^{* * *}$ & $0.311(1.305)$ & $1.002(2.523) * *$ & $0.508(1.722)$ * \\
\hline \multicolumn{5}{|l|}{ AC Diligence } \\
\hline Time and effort & $3.135(4.590)^{* * *}$ & $0.917(3.920)^{* * *}$ & $1.279(3.283)^{* * *}$ & $0.94(3.241) * * *$ \\
\hline AC meetings & $3.076(4.051)^{* * *}$ & $0.818(3.147)^{* * *}$ & $1.790(4.132) * * *$ & $0.467(1.452)$ \\
\hline \multicolumn{5}{|l|}{ AC Independence } \\
\hline AC non-executive members & $0.434(0.724)$ & $0.011(0.053)$ & $0.328(0.959)$ & $0.095(0.372)$ \\
\hline Qualifications and experience of board members & $0.864(1.829) *$ & $0.431(2.663) * * *$ & $0.573(2.127)$ ** & $-0.140(-0.700)$ \\
\hline Compensation of $\mathrm{AC}$ members & $-0.629(-0.908)$ & $-0.525(-2.212) * *$ & $-0.605(-1.531)$ & $0.501(1.706) *$ \\
\hline AC Resources & $-0.129(-0.185)$ & $0.082(0.341)$ & $-0.003(-0.008)$ & $-0.208(-0.700)$ \\
\hline
\end{tabular}

Panel B: Country-level Determinants of ACE

\begin{tabular}{lllll}
\hline Legal and regulatory environment & $-1.96(-2.987) * * *$ & $-0.643(-2.862)^{* * *}$ & $-1.12(-3.037) * *$ & $-0.180(-0.646)$ \\
Accounting and auditing environment & $1.061(1.984) * *$ & $0.586(3.202) * * *$ & $0.506(1.660) *$ & $-0.032(-0.141)$ \\
Government intervention & $-0.567(-0.860)$ & $-0.550(-2.436) * *$ & $-0.276(-0.733)$ & $0.259(0.925)$ \\
\hline
\end{tabular}

Panel C: Control Variables

\begin{tabular}{lcccc}
\hline Stakeholder group 1 & $4.903(1.088)$ & $0.330(0.214)$ & $2.495(0.970)$ & $2.078(1.087)$ \\
Stakeholder group 2 & $2.916(0.620)$ & $-0.217(-0.134)$ & $1.852(0.690)$ & $1.281(0.642)$ \\
Stakeholder group 3 & $-4.013(-0.557)$ & $0.092(0.037)$ & $-2.531(0-.616)$ & $-1.574(-0.515)$ \\
Type of qualification & $-8.739(-1.531)$ & $-0.281(-0.144)$ & $-5.642^{*}(-1.732)$ & $-2.817(-1.164)$ \\
Experience & $0.224(0.088)$ & $0.347(0.399)$ & $0.595(0.410)$ & $-0.718(-0.666)$ \\
\hline Constant & $28.87(3.025)^{* *}$ & $6.335(1.938)^{*}$ & $13.767(2.528)^{* *}$ & $8.76(2.166)^{* *}$ \\
Adjusted R & 0.485 & 0.377 & 0.403 & 0.277 \\
F-value & 11.742 & 7.908 & 8.711 & 5.377 \\
\hline
\end{tabular}

Note: The research variables are operationally defined in Table 2. Stakeholder group 1 is measured as 1 if the participant was a board member (including AC members) and 0 otherwise. Stakeholder group 2 is measured as 1 if the participant was an executive manager and 0 otherwise. Stakeholder group 3 is measured as 1 if the participant was an auditor (internal or external) and 0 otherwise. Type of qualification is measured as 1 if the participant holds a qualification in accounting, finance and economics and 0 otherwise. Experience is measured as 1 if the participant has a professional experience exceeding 5 years and 0 otherwise. Coefficients are in front of the parenthesis. ${ }^{* * *},{ }^{* *}$ and ${ }^{*}$ denote $p$-value is respectively significant at the levels $1 \%, 5 \%$ \& $10 \%$. 